Bulletin d'Histoire Contemporaine de l'Espagne

$50 \mid 2016$

Les intellectuels en Espagne, de la dictature à la démocratie (1939-1986)

\title{
Teoría y práctica de la Transición: el papel de los intelectuales
}

Théorie et pratique de la Transition: le rôle des intellectuels

theory and practice of the Transition: the role of the intellectuals

\section{Paul Aubert}

\section{OpenEdition}

\section{Journals}

Edición electrónica

URL: http://journals.openedition.org/bhce/576

DOI: $10.4000 /$ bhce. 576

ISSN: 1968-3723

Editor

Presses Universitaires de Provence

Edición impresa

Fecha de publicación: 1 diciembre 2016

Paginación: 127-162

ISSN: 0987-4135

\section{Referencia electrónica}

Paul Aubert, «Teoría y práctica de la Transición: el papel de los intelectuales », Bulletin d'Histoire Contemporaine de l'Espagne [En línea], 50 | 2016, Publicado el 09 octubre 2018, consultado el 18 septiembre 2020. URL : http://journals.openedition.org/bhce/576 ; DOI : https://doi.org/10.4000/bhce. 576 


\section{Teoría y práctica de la Transición: el papel de los intelectuales}

\section{Paul AUBERT}

Aix-Marseille Université, CNRS, UMR 7303 TELEMME

"Pitié pour nous qui combattons toujours aux frontières de l'illimité et de l'avenir " "Tened piedad de nosotros que luchamos siempre en las fronteras de lo ilimitado y del porvenir" « La Jolie rousse », Guillaume Apollinaire

«Vivimos en una época de Transición y de fluencia. En rincón ninguno de la tierra hallaremos unidad ideológica y sentimental.» Ramón Pérez de Ayala « Público, pueblo y plebe », El Sol, 24 novembre 1927.

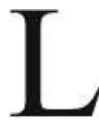
a historiografía de la Transición fue bastante desequilibrada y aunó paradójicamente el estudio de lo hondo y lo efímero, la Movida y la Constitución, la amnesia y la saturación de la memoria. A veces los testigos se congregaron para orientar la labor del historiador, confundiendo un antecedente con una causalidad. Relegaron la II República al rango de «experiencia», lo que tuvo como consecuencia la homologación del golpe de Estado franquista como necesidad catártica. $\mathrm{O}$ la elevaron, con algunas figuras del exilio, al rango de imprescindible herencia democrática.

Temática y temporalmente se han estudiado más los años de la bisagra que abre sobre los tiempos nuevos que aquellos mismos, y más el consenso que la discrepancia de algunos colectivos, hasta convertir la Transición, no ya en método que sustituyó un orden jurídico por otro, sino en acontecimiento democrático fundacional, más fácil de conmemorar que las efemérides de los años treinta.

El relato oficial, reproducido por algunos historiadores, dice 'entrere la muerte de Franco en 1975 y el frustrado golpe de Estado de Tejero-Armada, en febrero de 1981, las élites políticas del franquismo fueron magnánimas, que la clase obrera aceptó un plan de ajuste económico que inauguró un neorregeneracionismo para luchar contra la inflación (Pactos de la Moncloa), y que'élitete empresarial hizo más concesiones que nunca. Según esta visión angelical, España llegó a ser un país de Jauja en el que los líderes de la oposición al franquismo y los reformistas del interior pactaron un calendario para preparar la entrada en Europa del país y garantizar la democracia y el progreso. En cuanto a los exiliados, tuvieron que adaptarse al discurso del consenso so pena de desaparecer en los limbos de la historia. Todo ello bajo la vigilancia del rey Juan Carlos en una monarquía restaurada que acabó siendo causa y consecuencia de la Transición a la democracia. Este proceso de sustitución gradual de un régimen despótico por otro democrático -que fue la ilustración de una corriente de cambio iniciada con la Revolución de los claveles, en abril de 1974, y 
cerrada con la caída del muro de Berlín- llegó a ser una referencia para unos movimientos parecidos que brotaron por Hispanoamérica y la Europa del Este.

Más allá de este cuento de hadas, que blanquea el franquismo y supedita la importancia del exilio a su posterior homologación por la intelligentsia del interior, se cuestiona el papel de los intelectuales en este proceso transitorio, cuando, después de haber sido confrontados a la represión y a la desaparición del debate social, se requirió de nuevo su explicación del presente o su visión del porvenir inmediato. En ella están involucradas tres Españas: la de dentro y su oposición que va saliendo de la clandestinidad y la del exilio. Ahora bien, despertar al pueblo oprimido y a la nación dormida (viejo empeño del intelectual liberal ${ }^{1}$ ) implicaba la formulación de un proyecto. Para hacer compartir el «sueño de una revolución constitucional») (aquel que denunciara Araquistáin en 1934, por demasiado burgués ${ }^{2}$ y que volvía ahora con el concepto de «ruptura pactada») hacía falta reconstruir la razón ${ }^{3}$ y reencontrarse con la tradición democrática que simbolizaba la «España peregrina». Lo cual implicaba, tras la liquidación del intelectual tradicional por el franquismo y tantos años de exilio, de clandestinidad o de oposición más o menos explícita al régimen, la definición de un nuevo intelectual ${ }^{4}$ y la evaluación del alcance de su pensamiento y de su acción en la preparación de la Transición a la democracia ${ }^{5}$. Pero era difícil buscar las raíces morales de la nueva democracia española en el viejo orden constitucional y en la crítica interior al régimen y la forma definitiva del Estado hacia la que tendía este work in progress al que no se había fijado término. Algunos autores le asignan a este proceso un tiempo muy superior al meramente jurídico o señalan que éste no ha terminado todavía ${ }^{6}$. Es posible que los males actuales procedan de este olvido, de lo que se dio en llamar «los agujeros negros» de la Transición (Santiago Carrillo). Más allá de los episodios de la lucha de los intelectuales y de la interrogación sobre su conciencia histórica, cabe interrogarse sobre los fundamentos y el alcance de éstas en la ambigüedad de un período que acabó siendo constituyente.

1 Paul Aubert, La frustration de l'intellectuel libéral. Espagne 1898-1939, Cabris, Sulliver, 2010.

2 Luis Araquistáin, «La utopía de Azaña», Leviatán, núm. 5, septiembre de 1934.

3 Tomo esta fórmula de Elías DiAz, Los viejos maestros: la reconstrucción de la razón, Madrid, Alianza Editorial, 1994.

4 Véase, por ejemplo, Irene Moreno Moreno, «Pensar es sospechoso. El antiintelectualismo oficial durante la posguerra franquista», en Ángeles Barrio Alonso, Jorge de Hoyos PUENTE, Rebeca SaAvedra Arias (coords.), Nuevos horizontes del pasado: culturas políticas, identidades y formas de representación, Santander, 2011 (formato digital).

5 Sobre el particular, consideramos más significativas las siguientes obras : José Félix TeZanos, Ramón Cotarelo y Andrés de Blas (eds.), La Transición democrática española, Madrid, Sistema, 1989; Javier Tusell, La Transición española a la democracia, Madrid, Historia 16, 1991; Ramón Cotarelo (comp.), Transición política y consolidación democrática. España (1975-1986), Madrid, Centro de Investigaciones Sociológicas, 1992; Joaquín Prieto, Santos Julia y Javier Pradera (coords.), Memoria de la Transición, Madrid, Taurus, 1996; Álvaro Soto Carmona, Transición y cambio en España (19751996), Madrid, Alianza, 1996; Charles Powell, España en democracia, 1975-2000, Barcelona, Plaza \& Janés, 2001; Nicolás SARTorius y Alberto SABIO, El final de la dictadura. La conquista de la democracia en España (noviembre de 1975-junio de 1977), Madrid, Temas de Hoy, 2007; y Ferrán Gallego, El mito de la Transición. La crisis del franquismo y los origenes de la democracia (1973-1977), Barcelona, Critica, 2008.

6 Francisco Umbral, «La Transición », El País, 21 de septiembre de 1983. Véase también, Fernando JAUREGU, "Areilza y Carrillo coinciden en señalar que España vive aún la transición política», El País, 30 de septiembre de 1983. Santiago Carrillo, Memoria de la Transición. La vida política española y el PCE, Barcelona, Grijalbo, 1983. 


\section{Reconstruir la razón}

La guerra significó el destronamiento del intelectual tradicional que firma manifiestos, pronuncia discursos públicos y redacta artículos de prensa. Al Ortega y Gasset que comprobaba orgulloso, en 1927, que éste lo era todo -era quien escribía la historiasucedió otro en 1940, capaz de teorizar de nuevo su propia situación: el intelectual había acabado por no ser nada ${ }^{7}$. Después de la tragedia, en la sociedad de la posguerra, donde los triunfadores fueron vengativos y culparon a los intelectuales, parecía pues que no había sitio para el intelectual.

Al final del franquismo faltaba todavía la condición necesaria a la discusión intelectual, el reconocimiento de la alteridad, en un lugar donde la cruzada iniciada por la extrema derecha había convertido la idea en dogma y a medio país en anti-España. Por fin, la ley Fraga de 1966, que no fue ningún paradigma de las libertades, relajó la práctica que instauró la ley de Serrano Suñer de 1938.

\section{Teorías de la Transición}

Espíritus falsamente cándidos ven una «pretransición» en el empeño de Franco en dotarse de leyes en los años 60, tras el Fuero del trabajo elaborado por el régimen de Burgos durante la Guerra civil, (ley orgánica del Estado, en 1967; ley de sucesión, en 1969) dándose la mínima cobertura formal para ser aceptado a nivel internacional. Les conviene ignorar que una constitución la redacta una asamblea constituyente elegida al sufragio universal. Pero el «desarrollismo» ilustrado por la participación de miembros del Opus dei al Gobierno había cambiado las mentalidades políticas. Tal fue la tesis del ex ministro Laureano López Rodó cuando explicó que había ideado la futura democracia consiguiendo que Franco designara a Juan Carlos de Borbón como sucesor a título de rey ${ }^{8}$. Pero éste aceptó entonces «la legitimidad política surgida del 18 de julio de 1936 y se trataba de dibujar un régimen que garantizara cierta continuidad.

Francisco Ayala cuenta que propuso otra modalidad que hubiera permitido asociar cambio y continuidad : cuando Ramón Bela le invitó a comer con Fraga, el $1^{\circ}$ de julio de $1963^{\circ}$, le sugirió al ministro de Información y turismo: «un paso hacia la normalidad sería que el general Franco se redujera al título de Jefe de Estado, que no implica decisión acerca de la forma monárquica o republicana (todavía el príncipe Juan Carlos no había sido designado sucesor al trono), y nombrara un presidente de gobierno. Esto daría al régimen cierta flexibilidad, al separar la función ejecutiva de la meramente representativa $\rangle^{10}$. El nombramiento de Carrero Blanco, enemigo del liberalismo y de la democracia, como presidente de Gobierno en 1973, no ilustra precisamente este método de transición.

Cuando comprobaron que tenían que proponer una nueva definición del Estado y que no podian contentarse con glosar o reproducir el vocabulario de la democracia, los intelectuales de izquierda fueron más mentores que actores (cabe exceptuar a Armando López Salinas, pero éste desempeñó un papel político en el seno del PCE), ofreciendo un marco conceptual, unos órganos de reflexión, y dibujando a veces un modelo de reconciliación. Pues los que

7 José Ortega y Gasset, «El intelectual y el otro», Obras Completas, Madrid, Alianza ed., 1983, t. V, p. 511.

8 Véase el comentario de Santos JuLIÁ, "La "verdadera democracia" ", El País, 22 de octubre de 1992.

9 Fraga dijo luego que Ayala era «un gran escritor pero no una buena persona» (Manuel FraGA IRIBARNE, Memoria breve de una vida pública, Barcelona, Planeta, 1983, $1^{\circ}$ de julio de 1963 ).

10 Francisco Ayal., Recuerdos y olvidos, Madrid, Alianza ed., 1988, p. 502. 
esperaron una izquierda alternativa tuvieron que resignarse a la socialdemocracia pactista, que logró también la homologación de los antiguos miembros del PCE tras el descalabro de éste en las elecciones de 1982 mientras la nueva izquierda era soluble en un PSOE renovado.

Tras el consenso, ilustrado negativamente por el lema inventado por Francisco Umbral comparando las marginaciones de ambos políticos a la izquierda y a la derecha $-\ll \mathrm{Ni}$ Carrillo, ni Areilza» ${ }^{11}-$, venía la desilusión, la impresión de que la joven generación llegaba demasiado tarde, este mismo desencanto que Vázquez Montalbán procuraba suavizar citando versos de Pavese: «a este recuerdo sonríe y contesta que el sol /se levantaba sobre un día ya viejo para ellos» ${ }^{12}$.

En los últimos años, los temas debatidos (o parcialmente silenciados), en torno a la índole del Estado o de los nacionalismos, se transformaron en juicio sobre la misma Transición y el papel de unos y otros hasta llegar a valorar el testimonio de los supervivientes y, por consiguiente, el pasado republicano. Pero esta política de la memoria que desemboca sobre la necesidad de tratar con justicia a las víctimas, difícilmente podía enfocarse obviando el necesario distanciamiento crítico del historiador ni desde un gobierno de derechas que volvía a insistir sobre el carácter totalitario de la «experiencia republicana» y el hecho de que finalmente el orden público se le fue de las manos a Azaña. Empezaba a enarbolarse el «todos culpables» con el que algunos historiadores de moda habían buscado un éxito de librería.

La Transición designa a la vez una época y una categoría histórica cuyo estudio falla en cuanto se pretende entender el papel de los intelectuales en el proceso razonando en términos tradicionales con un análisis de los lugares de formación, medios de comunicación y vías de acción ${ }^{13}$. Primero, porque éstos no forman un grupo sino varios y porque tampoco el exilio es unívoco, ni el franquismo, ni la crítica interior a este régimen. Segundo, porque los medios de comunicación que simbolizan la oposición al franquismo, como Cuadernos para el Diálogo y Triunfo, no sobreviven al triunfo de sus ideas, en cuanto la sociedad les asimiló a la etapa de esta oposición porque esperaba nuevos modelos en un contexto en que una nueva prensa independiente estaba buscando su público ${ }^{14}$. La nueva intelligentsia posibilista fundó El País, el único diario que logró estabilizarse, con El Mundo, luego, mientras a lo largo de los años siguientes muchos títulos nuevos desaparecen (Diario 16, El Independiente) o no logran captar un público (El Sol etc. $)^{15}$.

Es probable que Triunfo se haya agotado con una labor pedagógica, siendo el vector de una ideología que se apagaba, porque era difícil forjar una nueva realidad sin dejar de criticarla al mismo tiempo. Triunfo enfatizaba los impulsos democráticos o meramente participativos de la sociedad, y sobre todo con la terquedad de su militancia léxica, que

11 Francisco Umbral, Y Tierno Galván ascendió a los cielos, Barcelona, Seix Barral, 1990, p. 120.

12 Cesare PAVESE, «I mari del sud», Lavorare stanca, 1936. « Ma quando gli dico ch'egli è tra i fortunati che han visto l'aurora /sulle isole più belle della terra, / al ricordo sorride e risponde che il sole/ si levava che il giorno era vecchio per loro. " La traducción es nuestra.

13 Paul Aubert, Les intellectuels espagnols et la politique dans le premier tiers du XX' siècle, Tesis de Estado, Univ. de Bordeaux III, Lille, ANRT, 1996.

14 Alicia Alted, Paul Aubert (eds.), Triunfo en suépoca, Madrid, Casa de Velázquez-ediciones Pléyades, 1993 ; Gabriel Plata, La razón romántica. La cultura politica del progresismo español a través de Triunfo (1962-1975), Madrid, Biblioteca Nueva, 1999; Eduardo G. Rico, Vida, pasión y muerte de Triunfo, Madrid, Ediciones Flor del viento, 2002; Javier Muñoz Soro, Cuadernos para el Diálogo (1963-1976). Una historia cultural del segundo franquismo, Madrid, Marcial Pons, 2006.

15 Aparecen veinticinco diarios nuevos para un lectorado compuesto por un $66 \%$ de miembros de clases acomodadas y un $15 \%$ de clases desfavorecidas (Gloria GARcia GonzÁLez, La ruptura comunicativa como respuesta democrática, Tesis doctoral, universidad de Salamanca, 2004, p. 79). 
consistió en medir el peso de las palabras, interpelando el nuevo poder a partir de su propio discurso, cuando todavía algunos temían las consecuencias de la democracia otorgada, que evocaban Fraga o Areilza: «No deben faltar nunca para que exista una democracia: libertad de expresión y de opinión, sufragio universal secreto, partidos políticos libres, parlamento enteramente elegido» ${ }^{16}$, porque "sin el juego de mayoría que gobierna y oposición que ofrece alternativas no hay democracia. $\rangle^{17}$

\section{Prácticas: de la cultura a la política}

Tras haber ganado la batalla cultural, convirtiendo la cultura en vector de militancia antifranquista, les tocaba pues a los intelectuales concretar al nuevo Estado; lo cual imponía pensar una continuidad a posteriori -como lo hicieran los republicanos al invocar a los Comuneros de 1520 para explicar el 14 de abril de 1931-y sugería flexibilidad conceptual, para evitar que la Transición acabara perteneciendo al lenguaje de la modernidad más que al de la historia. Hubo pues una cultura de la Transición, es decir una intuición de que de la definición histórica de este período dependía el porvenir del país, hasta lograr convencer de que D. Juan Carlos de Borbón fue partero de las libertades más que artefacto de la dictadura.

Pero la Transición es tanto un proyecto como un período y, por consiguiente, un proceso indefinido cuyo estudio atañe en parte al historicismo de algunos observadores que se solapa con el enfoque teleológico de la versión oficial. Mientras las guías turísticas iban poblándose de paradojas, muy pocos autores tuvieron la humildad de Robert Escarpit cuando, negándose a aceptar tópicos o clichés, advertía: « Lo que no sabemos [...] es la silueta de la nueva España que se edificó desde una generación detrás de la fachada, y que nos será revelada cuando caiga esta pantalla de humo» ${ }^{18}$.

Una nueva España se había construido solapadamente con la reivindicación de la nueva cultura que acabó deslegitimando al franquismo. Ésta pudo conjugar varios ritmos sin traducirse siempre con el cambio de lenguajes y de mitos que suelen reivindicar las vanguardias desde un enfoque cultural. Pero no bastó para hacer olvidar el aspecto determinista de una Transición definida a priori y a posteriori como anuncio o justificación de una política o de un código narrativo (y conceptualizada como fin y no como medio).

Pues se hizo hincapié en la débil movilización social del momento -que hubiera posibilitado la Transición-, olvidando que sólo en Madrid, entre 1976 y 1987, hubo treinta y siete manifestaciones de más de 100000 personas $^{19}$. También fue activo el movimiento obrero al protagonizar tras la muerte de Franco numerosas huelgas (1 568 en 1976; más de 18000 a lo largo de la década 1976-1986) ${ }^{20}$. Pero las estadísticas son tozudas: «Se ha vendido una imagen de la Transición que no tiene nada que ver con la realidad, porque no fue modélica, y hay que ponerla en su sitio [...] Se hicieron las cosas muy mal y se blanqueó

16 Editorial, «La respuesta democrática », Triunfo, 10 de enero de 1976, p. 5.

17 Eduardo Haro TeCGlen, «El pacto nacional », Triunfo, 22 de mayo de 1976, p. 9.

18 «Ce que nous ne savons pas [...] c'est la silhouette de la nouvelle Espagne qui s'est construite depuis une génération derrière la façade, et qui nous sera révélée lorsque tombera ce rideau de fuméen, Le Monde, 21 de noviembre de 1981.

19 Según Ramón Adell Argilés, La Transición politica en la calle : manifestaciones politicas de grupos y masas, Madrid, Universidad Complutense, 1976-1987, 1989, vol.1, p. 461-465 ; " Manifestations et transition démocratique en Espagne "), Les cahiers de la sécurité intérieure, París, n², 1997, p. 203-222.

20 José Antonio Maravall, La política de la Transición, 1982, p.161; Álvaro Soto Carmona, " Conflictividad social y Transición sindical », en Javier Tusell y Álvaro Soto CARmona, Historia de la Transición (1975-1986), Madrid, Alianza ed., 1996, p. 363-408. La estadística de huelgas: p. 374. 
el franquismo. En la Transición hubo muertos de los que no se habla, asesinados a manos de la policía, la guardia civil y la extrema derecha manejada desde el ministerio del Interior», afirma Alfredo Grimaldos ${ }^{21}$. Pero silenciar las resistencias haría correr el riesgo de dotar la traducción política de este movimiento de todas las expectativas de la modernidad, cuando se exigía la homologación de una victoria. En esta práctica se incrementó una noción para designar el «pasado que no pasa»: la memoria, presentada como presente eterno, yermo sobre el que no puede actuar todavía la mirada crítica de la investigación histórica ${ }^{22} \mathrm{o}$ al que sólo se aludiría para construir un relato histórico oficial ${ }^{23}$. Pero esta memoria es plural, insegura e ideológica y la tergiversan también varias versiones emitidas por ciertas comunidades autonómicas.

El papel de los estudiantes en la oposición a la dictadura no puede menoscabarse. Dentro de los dos grupos movilizados desde 1956, Pedro Laín Entralgo distinguió entre una «minoría activa y operante», inquieta por el futuro de España, y una masa disponible, radicalizable ${ }^{24}$. Esta radicalización, comprobada, a principios de los sesenta, en el seno de nuevas organizaciones estudiantiles como la Federación Universitaria Democrática Española (FUDE $)^{25}$, y el fracaso del franquismo en su intento por atraerse a los estudiantes al Movimiento, según lo lamentaba un informe de Rodolfo Martín Villa: «La juventud se nos ha ido $)^{26}$. Los esfuerzos del régimen para encauzar la corriente juvenil a través del Sindicato Español Universitario (SEU) resultaron vanos o se vieron desbordados por la oposición y la difusión de una cultura antifranquista ${ }^{27}$. Tampoco-descartaron la práctica del «entrismo» con el fin confesado de «abrir cauces», aprovechando las posibilidades que ofrecía la legislación ${ }^{28}$. Quisieron recuperar la memoria censurada o tapada por ésta, con libros publicados en el extranjero e introducidos clandestinamente. Luego leerían los fascículos que Historia 16 o Tiempo de Historia dedicaban a la historia de los siglos XIX y XX desde el episodio de las Cortes de Cádiz hasta la República y la Guerra civil. Se trataba de una memoria ocultada o, peor, tergiversada más que de aquella mirada moral al pasado de quien quisiera ser digno de la confianza de sus maestros.

21 Alfredo Grimaldos, La sombra de Franco en la Transición, Madrid, Oberon, 2004. Libro en el que se recuerda a «decenas de manifestantes que reclamaban amnistia y libertad en las calles [que] fueron asesinados por miembros de las fuerzas policiales y elementos de la extrema derecha ». Del mismo autor Las claves de la Transición 1973-1986, Barcelona, Peninsula, 2013. Véase también, Sophie Baby, Le mythe de la transition pacifique. Violence et politique en Espagne (1975-1982), Madrid, Casa de Velázquez, 2012.

22 Juan José Carreras Ares, « ¿Por qué hablamos de memoria cuando queremos decir historia ? ", en C. Forcadell y A. Sabio (eds.), Las escalas del pasado, Barbastro, IES-UNED, 2005, p.24.

23 Tal fue el debate suscitado, tras la formación del primer gobierno del Partido Popular, por los movimientos a favor de la recuperación de la " memoria histórica », que piensan que el proceso de transición a la democracia estriba en el silencio o la amnesia. Demuestra lo contrario Santos Juliá, en « El retorno del pasado al debate parlamentario. 1996-2003", Alcores. Revista de Historia Contemporánea, n 8, 2009. Véase también, S. Juliá, Hoy no es ayer. Ensayos sobre la España del siglo XX, Barcelona, RBA, 2010.

24 Pedro Lain Entralgo, La situación espiritual de la juventud española, Madrid, 1955, informe citado por Roberto Mesa (ed.), Jaraneros y alborotadores. Documentos sobre los sucesos estudiantiles de febrero de 1956 en la Universidad Complutense de Madrid, Madrid, UCM, 1982, p. 45.

25 Jordi Solé Tura, Una història optimista. Memòries, Barcelona, Edicions 62, 1999, p. 128.

26 Rodolfo Martín Villa, Incorporación al Movimiento de la juventud universitaria, citado por Pere Ysàs, Disidencia y subversión. La lucha del régimen franquista por su supervivencia, 1960-1975, Barcelona. Crítica, 2004, p. 220.

27 «Informe de don Pedro Laín Entralgo ..., op. cit., p. 45-53.

28 J.A. Maravall, Dictadura y disentimiento político. Obreros y estudiantes bajo el franquismo, Madrid, Alfaguara, 1978, p. 175. 
Tras una etapa reformista, anterior a 1968, con la constitución del Sindicato Democrático de Estudiantes de 1967, y otra más radical, hasta 1978, que se caracterizó por la voluntad de abrir la universidad a todas las clases sociales, las reivindicaciones fueron más políticas que académicas. Nuevos grupos trotskistas, marxistas-leninistas o maoístas habían aparecido que querían ser la vanguardia de la clase obrera, en un momento de movilización obrera en los demás países de Europa. Y el movimiento estudiantil fue plural: comunista (PCE-PSUC), socialista (Agrupación Socialista Universitaria), además de un Frente de Liberación Popular, un grupo de católicos y marxistas heterodoxos, además de grupos marxistas leninistas, maoístas y trotskistas.

Entre los partidarios de las elecciones para cargos representativos hijos de vencedores y de vencidos empezaban a compartir las mismas reivindicaciones, a firmar los mismos manifiestos y a protagonizar las mismas manifestaciones en un contexto todavía maniqueo ${ }^{29}$.

En pocos meses, los miembros de la nueva generación que entraba en las aulas a principios de los años 50, llamada «inocente» porque sus miembros eran niños en tiempos de la guerra dijo querer «evitar esta vida mecánica y gris de la mayoría de los estudiantes y [afirmar] el gusto, cada uno a su manera y tendencia, por los conceptos modernos de la existencia humana, de la cultura y del arte ${ }^{30}$. Se unieron a la batalla cultural del antifranquismo con el deseo de satisfacer interrogaciones existenciales o políticas que no encontraban respuestas en la sociedad de aquel entonces y adoptaron el grito de rebeldía generacional del cantautor catalán Raimón : «Diguem no». Esta negación, la compartieron algunos mayores, disconformes, como José Luis López Aranguren explicando que se trataba de "saber decir "no" a las injusticias, conocer y rechazar las manos que matan y las que mandan matar; buscar a tientas y a gritos [...] una nueva salvación para todos» $)^{31}$.

El intelectual que había nacido como crítico de la aplicación de la democracia liberal en un espacio público de debate, se vio reducido pues, tras la guerra y el franquismo, con la desaparición del espacio público conquistado a duras penas por el liberalismo, a una protesta indirecta de índole cultural. Durante el franquismo, hubo dos tipos de intelectuales: los «verdaderos» y «los falsos», es decir una sola modalidad aceptable. La misión de los primeros, que legitimaban el poder, era perseguir a los segundos, a los «malos maestros», que eran para ellos unos equivocados ${ }^{32}$. Mientras la geografia del exilio iba poblándose de ensayistas y pensadores, nacieron pues en esta España maniquea, unos intelectuales cabal o complacientemente «fascistas», dispuestos a construir el nuevo Estado de Franco con una emulación a veces conflictiva con los católicos: Rafael Sánchez Mazas, Dionisio Ridruejo, Gonzalo Torrente Ballester, Ernesto Giménez Caballero, Camilo José Cela, José Luis L. Aranguren, Joaquín Ruiz Giménez o Pedro Laín Entralgo, Antonio Tovar o Antonio Maravall, son los más conocidos.

29 Santos Julı̇, Elogio de la historia en tiempo de memoria, Madrid, Marcial Pons, 2011, p. 219.

30 Curial, Barcelona, febrero de 1949.

31 Texto de la contraportada del disco de Raimón, 1964, citado por Antoni BAtista, Raimon. La construcció d'un cant, Barcelona, La Magrana, 2005, p. 59.

32 "Escorial», Arriba, Madrid, 4 de enero de 1942, citado en Isabel Moreno, "Pensar es sospechoso. El antiintelectualismo oficial durante la posguerra franquistas, comunicación del X Congreso de la Asociación de Historia Contemporánea, Santander, septiembre de 2010. 


\section{Del antiintelectualismo al posibilismo del Opus Dei}

Cumplida la revancha, se trató luego de conquistar la sociedad. Los intelectuales de Acción Española querían introducir principios fascistas en la tradición monárquica para afianzar la contrarrevolución ${ }^{33}$. El falangista católico, Pedro Laín Entralgo, desde la revista Escorial, o José Antonio Maravall, fundador de Nueva Revista, aconsejaban liquidar el constitucionalismo liberal ${ }^{34}$, mientras varios escritores o universitarios tales como Antonio Tovar, Torrente Ballester, Agustín de Foxá, Eugenio Montes, Asín Palacios, José Mª Pemán, Eugenio d'Ors, compartían la exigencia de fundar un Estado totalitario aunque fuera sobre " ruinas recientes » (A. de Foxá), antes de sugerir, consumidas las provocaciones, una síntesis del pensamiento de vencedores y vencidos.

Mientras la geografía del exilio iba poblándose de escritores y pensadores olvidados, habían aparecido en España unos intelectuales falangistas católicos dispuestos a aprovechar el vendaval de la Guerra civil para construir un nuevo Estado sobre fundamentos neotomistas. Al cabo de unos años, llegaron a ser «liberales» y algunos adquirieron una real dignidad. Esta condición o apelación pareció servirles de viático durante la dictadura y de patente democrática luego para posibles tiempos revueltos. Pero hicieron más opaco el camino que habían seguido hasta imposibilitar un estudio sereno de aquellos tiempos llamados por ellos a posteriori «predemocráticos». Después de haber ideado el régimen franquista, se pusieron a prever su fin y a contemplar las modalidades de una Transición democrática, hasta llegar a aparecer únicamente como estos liberales que llegaron a ser. Se refugiaron entonces en el papel de moralistas víctimas de la crisis del Estado franquista que no pudo transformarse en estado moderno a pesar de un intento final de racionalización del ejercicio del poder.

A lo largo del primer franquismo estos falangistas rechazaron cualquier tipo de arreglos con el liberalismo ${ }^{35}$ y creyeron que podían llevar a cabo su programa aunque lamentaban la falta de intelectuales católicos bien formados, capaces de intervenir en el ámbito político y social. Para desarraigar la tradición liberal y el laicismo, que les pareció contrarios a la esencia de España, cuando ejercieron el Poder no dudaron en depurar funcionarios, censurar libros o denunciar intelectuales. Según recordaría José Ma Pemán, no podía haber salvación para quienes optaron por lo antinacional, lo judío, lo marxista o lo masónico. El arzobispo de Salamanca, Pla y Deniel, señalaba el método: quemar a los falsos ídolos intelectuales ${ }^{36}$. Justificaba la Cruzada en la que no había lugar para el perdón ni la reconciliación y denunciaba las libertades: «Libertad absoluta de pensamiento, de palabra y de prensa. La afirmación de que el pensamiento delinque. Idolatría fetichista de los llamados intelectuales, aun cuando sus producciones científicas o literarias produjesen la desmoralización, la subversión social o la anarquía. Éstos han sido los postulados del pasado siglo y del primer

33 Pedro Carlos González Cuevas, Acción Española. Teología política y nacionalismo autoritario en España (1913-1936), Madrid, Tecnos, 1998, p. 184.

34 Pedro Laín Entralgo, « Nacimiento y destino de tres generaciones. II- Revisión nacionalsindicalista del 98 », Arriba España, 11 de junio de 1937 ; José Antonio Maravall, « Desterrar el liberalismo », Arriba, 27 de febrero de 1940.

35 José Andrés Gallego, ¿Fascismo o estado católico?, Coslada, Encuentro, 1997, p.109.

36 Enrique PLA Y DENIEL, « Los delitos del pensamiento y los idolos intelectuales », pastoral del 8 de mayo de 1938, Escritos pastorales, t. I, Madrid, 1946, p. 107-109; citada por Gonzalo Redondo, Historia de la Iglesia en España, t. II : La Guerra Civil, 1936-1939, Madrid, Rialp, 1993, p.465. 
tercio del presente en la gobernación de muchos pueblos y también en nuestra España. » Y acababa acusando a los universitarios ${ }^{37}$.

Los ideólogos de Acción Española creyeron que habían llegado tiempos favorables a una contrarrevolución antiliberal. Pero los intelectuales católicos discreparon a la hora de proponer un método: los católicos sociales de Acción Popular, apoyados por $\mathrm{M}^{\mathrm{gr}}$ Vidal i Barraquer, apostaban por una vía lenta reanudando con el catolicismo social de principios de siglo que les llevara a buscar un modus vivendi con la República, cuando los integristas de Renovación española y de Acción española, aprobados por $\mathrm{M}^{\mathrm{gr}}$. Isidro Gomá, el primado de Toledo, sucesor del cardenal Segura, preferían la acción directa e incluso insurreccional aunque carecían de una organización de tipo fascista, según lo comprobaba Ramiro Ledesma Ramos ${ }^{38}$, y contaban sólo con algunos jefes como Gil Robles (con sus Juventudes de Acción Popular) o Calvo Sotelo (con su Bloque Nacional). Disponían ya de un programa que Ángel Herrera Oria había redactado en 1933, en el que explicaba que los católicos debían considerar la proclamación de la República como un revulsivo para llevar a cabo una reconquista ideológica de España ${ }^{39}$. Habían emprendido una lucha contra los institucionistas a quienes acusaban de ejercer una influencia hegemónica en el ámbito de la enseñanza cuando los católicos no disponían, según el padre Enrique Herrera Oria, hermano del anterior, de una universidad propia. Unos meses después el doctor Suñer culparía a los intelectuales, en general, y a los institucionistas, en particular, de la tragedia española ${ }^{40}$.

Tras la derrota de lo que llamaban la « intelectualidad descreída», tanto los hombres de Acción Española como los católicos de Acción Popular y de Acción Católica habían pensado que los tiempos eran favorables a la lucha contra la secularización y la descatolización del país según decía Eugenio Montes. Se trataba de construir un nuevo poder acabando con el influjo marxista de los republicanos. « En España no quedaron más que los [intelectuales] católicos», recuerda Aranguren (tras Laín quien acababa de comprobar que el cristianismo volvió a gozar de «opción a la actualidad» " al emprender, lo mismo que García Escudero, una crítica del nacionalcatolicismo desde las conversaciones católicas internacionales de San Sebastián (1947-1959) y de Gredos (1951-años 1970) ${ }^{42}$ que reunieron en torno a los jesuitas Querejazu y Ceñal miembros del «grupo de Burgos»,

37 «¡Cuán tremenda es la responsabilidad en la actual tragedia de España de muchos profesores de Universidad [...] En un Estado comunista o socializante es lógico que se fomenten tales doctrinas y tales propagandas antirreligiosas, inmorales y pornográficas, socialistas, comunistas y anarquistas]. Lo que resulta un absurdo suicida es que en regímenes opuestos, en los cuales se reconocía el catolicismo como religión oficial de Estado y con Constituciones que consideraban la autoridad, la propiedad, el orden como bases fundamentales de la sociedad, se dejase socavar tales fundamentos por un culto supersticioso a la libertad, aun en sus excesos y en sus desvarios intelectuales, que pueden ser y son pecado ante Dios y delito y crimen ante una sociedad que quiera defenderse de hecatombes revolucionarias y de la anarquía. » (Ibid., p. 285-286).

38 Ramiro Ledesma Ramos, ¿Fascismo en España? Discurso a las juventudes de España, Barcelona, Ariel, 1968, (1ª ed., 1935), p.70.

39 Ángel Herrera OrIa, «Programa escolar de los católicos », 29 de julio de 1933, Obras Completas, II, Madrid, BAC, 1963, p. 113-114. Citado por Santos JuLı́, «Intelectuales católicos a la conquista del Estado », El nacimiento de los intelectuales en España, C. Serrano (ed.), Ayer, n 40, 2000, p. 82.

40 Enrique SUÑER, Los intelectuales y la tragedia española, Burgos, 1937, p. 6-22. Llegaron hasta aborrecer la figura «diabólica» de José Castillejo, secretario de la Junta para Ampliación de Estudios, «nido de masones y extranjerizantes», culpable de haber abierto España a los vientos de fuera.

41 Pedro Lain Entralgo, «El intelectual católico en la sociedad actual ", Ejercicios de comprensión, Madrid, Taurus, 1959, p. 46.

42 Olegario Gonzalez de Cardedal, Alfonso Querejazu. Conversaciones católicas de Gredos, Madrid, Biblioteca de Autores Cristianos, 1977. 
tales como Pedro Laín Entralgo, Dionisio Ridruejo, José Luis L. Aranguren, Luis Felipe Vivanco, Luis Rosales, Joaquín Ruiz Giménez. Acabaron considerándose un gueto dentro del régimen aunque uno acabaría siendo ministro y otro rector. Una democracia les parecía todavía imposible en un momento en que el régimen acababa de estrenar el Fuero de los Españoles, aunque luego algunos se convertirían en líderes de movimientos democráticos. « Se trata de una trayectoria que no se ha dado en ningún otro país: de la Falange a la democracia, del totalitarismo al sistema de partidos, del nacionalcatolicismo a los aledaños del protestantismo. Ellos fueron la clave de un movimiento pendular que iba a desembocar en lo que hemos dado en llamar la «Transición» y que no ha sido otra cosa que el final de una evolución larguísima que comienza en estas altitudes de Gredos. $»^{43}$

\section{Reforma del régimen franquista}

Un estudio de la Revista de Estudios Políticos (1941-1977), instrumento de integración de las distintas tendencias del bloque dominante y de las revistas de sociología muestra la influencia de la obra de Balmes y su importancia en la nueva sociología política franquista que prefería estudiar a la sociedad independientemente del Estado. Estos sociólogos fueron solicitados por el poder en materia de sociología del trabajo y de la familia. Sin practicar la encuesta sistemática, echaron las bases de una sociología empírica bastante alejada de los precursores venidos del derecho o de la filosofía. Se creyó pues que la sociología del cambio (mejor conocimiento del mundo del trabajo, teoría de la gobernabilidad) podía llegar a ser, si no un instrumento de gobierno, al menos una herramienta de prescripción social a la que estuvieron atentos los miembros del Opus Dei que apoyaron a Antonio Fontán o a Rafael Calvo Serer en su empeño en hacer surgir una opinión pública para reformar el régimen.

La reforma que desde dentro se intuía partía de la legalidad existente. Era sólo la legitimación de la evolución del franquismo hacia un régimen representativo - un amago de pluralismo que tomaba el Movimiento Nacional como base constituyente-, y no una construcción ex nihilo, Además no parecía claramente definida y consagraba la continuidad política del bloque de poder que, al aceptar el proceso de Transición, podía también reivindicar la responsabilidad de un cambio institucional que coincidía con la liquidación electoral del PCE y luego la bipolarización de la vida política. En este sentido se subrayó el papel de Dionisio Ridruejo quien habló desde mediados de los años sesenta de la necesidad de una Transición democrática ${ }^{44}$, hasta el punto de ser considerado recientemente «el primer hombre de la Transición $\rangle^{45}$.

Tras esta lenta consunción que acabó siendo el franquismo, el intimismo pareció adelantarse al compromiso. El discurso sobre la nación era demasiado especulativo en tal contexto cuando hacía falta construir lo inmediato. De hecho, les tocó a las élites liberales glosar un concepto nuevo, por no decir un oxímoron: la ruptura pactada. Este posibilismo, que no gustó a todos los exiliados, vulneraba sus tradiciones democráticas ante la eventualidad de pactar con franquistas reconvertidos en «demócratas de toda la vida», cuando la sociedad española demostraba su débil organización para acabar por sí misma con la dictadura.

43 César Alonso DE los Rios, «El péndulo de Gredos », $A B C, 9$ de octubre de 2003.

44 Dionisio Ridruejo, «El régimen y la Transición democrática », Mañana, París, n6, juin-julio de 1965, p. 12-14. Véase el apéndice a Dionisio Rıdrueıo, Escrito en España (Jordi Garcia ed.), Madrid, 2008.

45 Julio Bravo, "Dionisio Ridruejo. Una pasión española : El primer hombre de la Transición », (a propósito de la obra de teatro de Ignacio Amestoy), $A B C, 14$ de marzo de 2014. 
Había surgido, no obstante, un tímido pluralismo dentro del mismo régimen franquista que llevó a su autodisolución por la Ley de Reforma Social de Adolfo Suárez de 1976. La legalización de este pluralismo permitió una nueva agrupación de quienes habían gobernado desde 1939, mientras el presidente Suárez se esforzaba por señalar que no existían diferencias de objetivos entre la nueva oposición democrática y el régimen que él mismo había perfeccionado.

Un análisis de la evolución del discurso político-jurídico destinado a construir un Estado nuevo muestra la importancia simbólica que pudo cobrar el Derecho de petición (ley de 22 de diciembre de $1960^{46}$ modificada por la de 12 de noviembre de 2001 y previsto por el artículo 29 de la Constitución de 1978) a la hora de hallar en la misma legislación franquista los fundamentos de una evolución democrática puesto que estaría al origen de un sistema representativo.

Otros preferían, para olvidar o cortocircuitar la tradición liberal, encontrar en la ley sobre las convenciones colectivas de 1958 los cimientos de una cultura política democrática ${ }^{47}$, mientras López Rodó veía en la ley de 22 de diciembre de 1960 sobre el Derecho de petición los fundamentos de una evolución democrática en el mismo régimen franquista que hubiera propiciado una vuelta al régimen representativo. En realidad se trataba de reformar el régimen, no de instaurar una democracia ${ }^{48}$.

La oposición empezó a hablar entonces de ruptura, sin precisar las modalidades de la misma, mientras los gobernantes procuraban demostrar su buena voluntad. Dicho de otra manera, ambos campos se portaban como si la Transición dependiera de ellos cuando hubo que esperar las elecciones legislativas de 1979 para que se formara un sistema de gobierno abierto. Pero esta ficción parecía convenir a todos, tanto más cuanto que, durante el episodio constituyente, el Parlamento pudo ejercer un mínimo control sobre el Gobierno a través de interpelaciones previstas por la actividad rogatoria ${ }^{49}$. En efecto, tras la muerte de Franco, nadie llama, como en 1931, a la revolución política ni mucho menos social (aunque ésta se convirtió en democracia antes de ser denunciada como símbolo de un Estado burgués) pero se dibuja un consenso de parte de la nueva clase media, mejor integrada en la economía capitalista y no guiada, como en los años 20 , por unos intelectuales salidos de la enseñanza o de las profesiones liberales, sino por técnicos del mundo de la empresa o de los negocios, para fijar un horizonte democrático.

\section{El impulso de las clases medias}

Sin embargo, también «hubo una línea de continuidad y de relación causa-efecto entre la oposición a la dictadura, antes de 1975 , y el cambio a la democracia que va efectivamente

46 «Los españoles podrán dirigir individualmente peticiones al Jefe del Estado, a las Cortes, al Consejo de Ministros, a las Comisiones Delegadas, al Presidente del Gobierno y a los Ministros, en el ámbito nacional, y a los Gobernadores generales, Gobernadores civiles (En la actualidad Subdelegados del Gobierno) Subgobernadores y Delegados gubernativos, así como a las Diputaciones Provinciales, Mancomunidades Interinsulares, Cabildos Insulares, Ayuntamientos y sus respectivos Presidentes, en el ámbito local; y a las Representaciones Consulares tratándose de españoles residentes en el extranjero. » (Ley 92/1960, reguladora del derecho de petición, art. 2).

47 Santos JulıÁ, «Orígenes sociales de la democracia en España», en La Transición a la democracia en España, Manuel Redero (ed.), Ayer, n 15, p. 165-187.

48 Jorge de Esteban, Luis López Guerra, La crisis del Estado franquista, Madrid, Labor, 1977.

49 Jordi SOlè TURA, «El control parlamentario en el período constituyente y en la Constitución de 1978", en Miguel Ángel Aparicio Pérez (coord.), Parlamento y sociedad civil, Barcelona, Universidad de Barcelona, 1980, p. 31. 
lográndose después de esta fecha $\aleph^{50}$. La Transición no fue ningún milagro, pero tampoco fue una necesidad histórica, aunque la propiciaron evoluciones interiores, como la de la Iglesia, y exteriores, como la actitud favorable de las potencias occidentales, confirmada por los estudios que destacan la presencia de factores internacionales en la historia del antifranquismo y de la propia Transición.

Tras el intento franquista de detener la Historia para retrotraerla, mediante una simbología imperial a la época de los Reyes Católicos, el impulso de las nuevas clases medias y de la clase obrera había contribuido a la democratización llevada a cabo por el acuerdo de las élites franquistas y de la oposición. A partir de los años sesenta las ciudades volvieron a crecer y las capitales, Madrid y Barcelona, a atraer inmigrantes de los dos Castillas, de Extremadura o de Andalucía. A estas consecuencias de la urbanización se añade la evolución de las mentalidades de la joven generación. De tal manera, que todos los fenómenos de sociedad se asimilaron en España en un tiempo record. Un crítico literario, José Tono Martínez, director de La Luna de Madrid, evoca la consecuencia de estos cambios acelerados que rayaron a veces en desilusión y pasotismo en cuanto los hijos de los militantes antifranquistas se dieron cuenta de la frustración que vivieron sus padres, mientras tenían ellos la impresión de llegar tarde:

" En el corto espacio de diez años -explica- los madrileños nos hemos mamado asi, de sopetón, más novedades que un neoyorkino en toda su existencia. Desde que amanecieron un tanto amenazadores los primeros años setenta y nos descubrimos todos tan tontos y tan guapos repartidos por las cafeterías de Serrano los más privilegiados o trabajando de simpáticos botones de banco los menos agraciados, hemos ido o hemos podido ser de todo : comunistas románticos o convencidos, anarquistas provocadores, pasotas desencantados, fumadores de canutos, terroristas, jipis, yonquis, concienciados demócratas, abstencionistas, colgados de ácido, siquiatrizados, mods, punquis, neorrománticos, tirados, miembros del gobierno, retros, modernos y todas aquellas cosas que en otros territorios supusieron la culminación cultural de generaciones enteras. $\rangle^{31}$

«De 1962 a 1982 se produjeron los cambios más rápidos y profundos que España haya experimentado desde la caída del Antiguo Régimen y el advenimiento de la sociedad liberal», comprueba Santos Juliá ${ }^{52}$. Se abre pues una secuencia amplia de cambios a caballo sobre el final del franquismo muy superior a la cronología de lo que se dio en llamar la Transición política. Éstos se deben tanto a la coyuntura económica como al papel de ciertos semanarios o revistas y a la reflexión de intelectuales franquistas deseosos de adaptar el franquismo a la democracia o al contrario de intelectuales antifranquistas preocupados por compatibilizar la democracia con el sustrato franquista pero siempre desde la comprobación de la crisis de la democracia liberal.

Los primeros contemplaron la posibilidad de formas organicistas o tecnocráticas, los segundos enfocaron el porvenir desde formas socializantes o una tercera vía próxima al liberalismo social más que a las utopías revolucionarias de la nueva izquierda de los años sesenta. En tal contexto estos intelectuales pretendieron llevar a cabo una reeducación política y moral de la sociedad o expresar una precaria voluntad popular desde un diario moderado (Madrid,) revistas oficiales universitarias (la Revista de Estudios Políticos), o

50 Elias DiAz, « Las ideologias de (sobre) la Transición », in La Transición democrática española, José Félix Tezanos, Ramón Cotarelo, Andrés de Blas (eds.), Madrid, Sistema, 1989, p. 757-783.

51 Borja Casani y José Tono Martinez, «Madrid 1984: ¿La posmodernidad?» La Luna de Madrid, 1, 1983, p. 6-7.

52 Santos Julı́, « España en tiempos de Triunfo », Alicia Alted y Paul Aubert (eds.), « Triunfo » en su época, Madrid, Casa de Velázquez, 1995, p. 28. 
disidentes (Triunfo, Cuadernos para el Diálogo), predicando una vuelta a la ética o el diálogo con los marxistas. Estas revistas, cuya tirada no superaba los 60000 ejemplares, contribuyeron a la formación de unas jóvenes élites universitarias que se situaban entre el catolicismo liberal y el socialismo humanista a los que se unían figuras mayores del falangismo desilusionado, como Dionisio Ridruejo, Pedro Laín Entralgo o José Luis López Aranguren. Se beneficiaban también, como el diario Madrid, de un accionariado bastante conservador: Triunfo, respaldado por la empresa publicitaria Movierecord vinculada al Banco Atlántico, próximo al Opus Dei ${ }^{53}$; Cuadernos para el Diálogo, con una estratificación de mando mediante una empresa editorial controlada por grupos financieros que coexistían con accionistas militantes, una dirección desempeñada por personalidades liberales (aunque, por razones legales, Ruiz Giménez no pudo ser director) y una redacción compuesta por jóvenes periodistas opuestos al franquismo (pero se negó el carné de periodista a Pedro Altares y el director de la redacción fue Félix Santos).

Triunfo no renunció nunca al comentario de la actualidad ni Cuadernos para el Diálogo al debate ideológico: el carácter iniciático de ambas revistas es patente. Y cabe recalcar la presencia importante en las Constituyentes de antiguos colaboradores de Cuadernos elegidos en listas de todos los partidos del espectro ideológico desde UCD al PCE, mientras Triunfo ostentaba, frente a esta transversalidad, un anclaje político más estricto y más próximo al $\mathrm{PCE}^{54}$. También le tocaría a Antonio Fontán, director de Madrid en los tiempos difíciles, presidir el Senado en 1977.

Sin embargo, Triunfo (1962-1982) y Cuadernos para el Diálogo (1963-1978) no lograron sobrevivir a su papel de oposición, perdieron los ingresos publicitarios y desaparecieron cuando triunfaron las ideas que habían inculcado a la sociedad española. Ya habían pasado los tiempos en que llevar Triunfo debajo del brazo era un acto de rebeldía al alcance de los « pequeños hombres révoltés y camusíanos de provincia $($ sic $) »^{55}$. Pues un periodismo de hechos estaba postergando el periodismo de ideas que había nacido al amparo de la ley Fraga.

A esta sorpresa se unió el descubrimiento de la polémica en torno a la posmodernidad. Dicho de otra manera, los españoles descubrieron la modernidad política con la democracia al mismo tiempo que la posmodernidad ideológica renunciaba a lo que Jean-François Lyotard llamara «los grandes relatos» especulativos o emancipadores, es decir los relatos que legitimaban el saber y homologaban una conducta histórica ${ }^{56}$. El discurso sobre la Transición es sin duda uno de los últimos.

A partir de entonces se hizo hincapié en la cultura más que en la creación y en los medios más que en los fines. De tal manera que los españoles parecieron descubrir en esta discordancia una modernidad gastada. El desajuste era el mismo que cuando los intelectuales de los años treinta decían que venían a realizar los principios liberales proclamados en el siglo XIX. Ahora la trascendencia del momento obligaba a sacrificarlo todo al historicismo ambiente cuando no a la teleología. Quedaba poco margen para la improvisación, cuando bailar la sardana era una hazaña y aceptar la bandera monárquica un adeudo descomunal, mientras políticos del régimen, como Fraga o Areilza, habían preparado proyectos de

53 José Ángel Ezcurra, « Apuntes para una historia », A. Alted y P. Aubert (eds.), "Triunfo » en su época, Madrid, ediciones Pléyade-Casa de Velázquez, 1993, p. 48.

54 Isabelle RENAUDET, Un parlement de papier. La presse d'opposition au franquisme durant la dernière décennie de la dictature et la transition démocratique, Madrid, Casa de Velázquez, 2003.

55 Francisco Umbral, "Spleen de Madrid :Triunfo », El País, 4 de julio de 1980.

56 Jean-François Lyotard, La condition post-moderne, Paris, éd. de Minuit, 1979, p. 63. 
constituciones orgánicas y algunos medios diplomáticos aconsejaban excluir al Partido comunista del proceso de Transición.

\section{Una rebelión de las élites}

$¿$ Cabe hablar pues de las mutaciones del post-franquismo, olvidando precisamente que este después no es más que una referencia a un antes y que el post-franquismo conceptualmente, es todavía franquismo? Quizá no corresponda a este porvenir «atado y bien atado» que creía hipotecar el mismo dictador, pero estaba en la lógica misma de aquella " ciudad de Dios» que algunos falangistas, como Laín Entralgo, creyeron poder implantar como «realización histórica presente de la moral cristiana» ${ }^{57}$ tras haber vivido el triunfo de la intelectualidad republicana como una derrota. Se lanzaron a la reconquista del terreno perdido, cuando no a la contrarrevolución.

Otros explicitaron objetivos distintos, como el grupo reunido en torno a Calvo Serer y a la revista Arbor, más aferrado a la recuperación de una tradición española representada por Menéndez Pelayo y a la revalorización de la Historia de la unidad católica nacional ${ }^{58}$. Esta « generación del 48 », como les llamó Jaume Vicens Vives ${ }^{59}$ : Florentino Pérez Embid, Víctor García Hoz, Álvaro D’Ors, Vicente Marrero, Raimundo Paniker, Hans Juretschke, Ismaël Sánchez Bella, Olivar Bertrand o Vicente Palacio Atard etc. eran unos universitarios, obsesionados por la decadencia de su país a lo largo de la Historia. Buscaban el origen de la Guerra civil en el pasado y creían haber encontrado en la España de la posguerra civil el inicio de una nueva etapa histórica. Si Falange procuró desacreditar tanto al Opus Dei, al que muchos pertenecían (aunque Vicente Marrero lo desmintió,) como al CSIC, editor de la revista Arbor, esto se debe en gran parte a la desconfianza falangista hacia la apertura europea preconizada por este grupo ${ }^{60}$ que también se había abierto a numerosas personalidades conservadoras del interior como José Camón Aznar o Nicolás González Ruiz, o ex colaboradores de Acción Española, como Eugenio Vegas Latapié, José María Pemán o José Pemartín. La revista Arbor presentó la variedad ideológica de autores del franquismo hasta mediados de los años 50 en que Rafael Calvo Serer fue destituido tras la publicación de un artículo en París en el que criticaba la evolución interna del régimen ${ }^{61}$. Posteriormente, junto con Antonio Fontán, desde el reaparecido diario vespertino Madrid (1966-1971), apuntalado por el apoyo de un grupo financiero cercano al Opus Dei, Calvo Serer abogaba por la apertura política y se oponía al rapto de Falange por el régimen, intentando iniciar un debate social y quizás crear una tercera fuerza al lado de los falangistas y propagandistas de la ACNP. Lo cual ilustra la intervención creciente en los medios de comunicación, que empiezan a cobrar mayor importancia, de unos círculos financieros dispuestos a forjar una opinión (élites tecnocráticas, Asociación Católica Nacional de Propagandistas etc. que ya habian creado en 1957 la agencia Europa Press, y en 1960 una

57 José Antonio Maravall, "Laín Entralgo, Pedro. Los valores morales del Nacionalsindicalismo ", Revista de Estudios Políticos, $\mathrm{n}^{\circ}$ 3, julio de 1941, p. 567. José Luis López Aranguren, Memorias y esperanzas españolas, Madrid, 1969. Feliciano Montero García, « Los intelectuales católicos, del colaboracionismo al antifranquismo, 1951-1969 ", Historia del presente, n 5 , 2005, p. 41-68.

58 Rafael CALvo Serer, «Una generación española », Arbor, n²4, noviembre-diciembre de 1947, p. 334.

59 Comentario del libro de Vicente Palacio Atard, Derrota, agotamiento, decadencia, en la España del siglo XVII (Jaume Vicens Vives, «La generación del 48 », Destino, n 641, 1949, p. 15, citado por Sara Prades Plaza, España y su historia. La generación de 1948, Castelló, Universitat Jaume I, 2014, p. 99).

60 Véase Sara Prades Plaza, Ibid., p. 109-123.

61 Rafael Calvo SERER, «La politique intérieure dans l'Espagne de Franco », Écrits de Paris, $\mathrm{n}^{\circ} 107$, septiembre de 1953. 
emisora de radio, la COPE. Esta introducción del capital privado en una prensa en manos del Estado, de la Iglesia o de unas cuantas familias (La Vanguardia o $A B C$ fomenta el desarrollo en el que estriba la Transición política.

Otro factor fue el papel de algunos catedráticos juristas o politólogos, como Carlos Ollero, Tierno Galván, José Antonio Maravall, Raúl Morodo o Alfonso Ossorio ${ }^{62}$ etc. o la novedad de la propuesta aperturista de los altos funcionarios del grupo «Tácito», firmantes de una columna semanal en el periódico católico $Y a$, entre 1973 y $1977^{63}$, que participaron en su mayoría en los gobiernos de Adolfo Suárez (como Miguel Herrero de Miñón, Marcelino Oreja, Rafael Arias Salgado, Fernando Álvarez de Miranda, Leopoldo Calvo-Sotelo, Landelino Lavilla, Juan Antonio Ortega etc.). Del mundo empresarial vienen casi todos los dieciséis fundadores de Cambiol6 en $1971^{64}$. Frente a una temible «bunkerización» del poder se apostaba por una reforma del sistema desde dentro que tardaba en llegar a pesar de algunas discrepancias.

El primer caso conocido de disidencia fue el de Dionisio Ridruejo quien, al volver de la campaña de Rusia de la División Azul, dimitió de todas sus funciones políticas. Laín Entralgo, después de haber sido rector de la Universidad de Madrid entre 1951 et 1956, llegó a ser « paria oficial » como gustaba de llamarse a sí mismo. En cuanto a Aranguren, le expulsaron de su cátedra de ética y sociología en 1965. La polémica que rodea las obras de estos intelectuales puede entenderse en la medida en que engendran numerosas preguntas en torno a la personalidad de estos hombres, su sinceridad, sus ideas reales pasadas y presentes, su papel en el seno de la España franquista, su disidencia y por fin su influencia en el futuro democrático de la península. Pues estos falangistas, inicialmente apodados «presuntos fascistas» y luego «falangistas liberales» fueron apóstoles del consenso ${ }^{65}$, dispuestos a comparar la monarquía impuesta por Franco al periodo de incertidumbre que precedió el advenimiento de la II República tras el pacto de San Sebastián ${ }^{66}$.

A la Transición contribuyó pues esta «rebelión de las élites», según la expresión de Juan Francisco Fuentes, contra un régimen anacrónico. El desliz desde los resquicios aprovechables de la legalidad franquista hacia la democracia y la presencia de algunos miembros del régimen anterior lastra simbólicamente el proceso de Transición de todos las desilusiones de la generación de cuarentones que sabe que llegó tarde a la vida pública y estará apartada del poder, pero actúa de catalizador posibilitando el advenimiento pacífico del nuevo régimen. Pues nunca se ve un nuevo régimen capaz de prescindir de las élites del antiguo (servicios secretos, ejército, policía, economistas etc.) para llevar a cabo un proceso democratizador; tanto más cuanto que en España la liberalización de la economía precedió el cambio político. Se calificó a UCD de partido de subsecretarios, es decir cargos públicos de segundo grado que se distanciaron del viejo régimen sin renunciar a disponer del aparato del Estado: « unas jóvenes élites politicoadministrativas que, llegado el momento, defendieron desde algunas tribunas periodísticas la necesidad de sacrificar

62 Raúl Morodo, Atando cabos. Memorias de un conspirador moderado, Madrid, Taurus, 2001.

63 Charles Powel., « The "Tácito" Group and the Transition to Democracy, 1977-1977 », en F. Lannon y P. Preston (eds.), Elites and Power in Twentieth Century Spain. Essays in Honour of Sir Raymond Carr, Oxford, Claredon Press-Oxford University Press, 1990, p. 249-268.

64 Juan Francisco FuENTES, « Prensa y politica en el tardofranquismo (1962-1975). La rebelión de las élites ", Cercles. Revista d'Història Cultural, nº, enero de 2003, Universitat de Barcelona, p. 12-32.

65 Raúl Morodo, "La función político-social del 'consensus' », El País, 23 de septiembre de 1978.

66 José Luis Lopez Aranguren, "El consenso de la Moncloa y el « pacto » de San Sebastián », El Pais, 19 de agosto de 1978 . 
al régimen para salvar al Estado.» ${ }^{67}$ Los intelectuales de la oposición podían contentarse con la convicción de haber ganado la batalla cultural: « La cultura democrática empieza a organizarse », comprobaban ${ }^{68}$. Pero hacía falta lograr la paz para poder empezar la batalla política, es decir el debate democrático.

\section{Recuperar la tradición liberal}

Hacía falta una reeducación política y moral para terminar con el período « predemocrático». En algunos casos, la recuperación de los viejos maestros no era tarea fácil. Hacía falta evaluar el final de la vida de Unamuno, la huida desde el verano de 1936 de la «Tercera España» liberal y el posterior «exilio interior» de falangistas defraudados como Dionisio Ridruejo, Aranguren, Laín Entralgo etc., pero también considerar el legado político del exilio.

Al final de este periodo -la Transición breve, stricto sensu, la que se verifica en torno a la reforma de Adolfo Suárez-, la polarización de los partidos políticos acaba disolviendo, con el voto útil, el abanico ideológico salido del franquismo o de la oposición. También se han olvidado los hitos culturales ligados a las causas históricas perdidas. Pues cuando al vocabulario de la revolución, que todavía articulaba el lenguaje de la oposición al franquismo, se sustituyó el de la democracia, la dificultad era doble: ¿cómo explicar a los españoles una realidad democrática desaparecida con un léxico que desconocían y además era inadecuado o había sido descalificado por la retórica franquista?: «El primer artículo de la Constitución está lleno de palabras sagradas, que han ensangrentado la historia. Hoy se han convertido en simples conceptos de Derecho Político adquirido"), comprueba Manuel Vicent ${ }^{69}$, poco después de la apertura de las Cortes Constituyentes. Había que demostrar a diario que la democracia no era una herencia sino una realidad que se construye cada día con un vocabulario y una simbología nuevos. En tal contexto, se invirtió el esquema al uso para volver al modelo teórico: pues la Transición fue social y discursiva antes que política. En España, a partir de 1976, la Transición fue un apaño, el paso efímero de una realidad que no gustaba a otra cuya característica se desconocía. Por consiguiente, no cabe estudiar este proceso como tal sino en función de la situación a la que permite llegar. En este sentido, reforma del sistema franquista, recuperación de la tradición liberal e impulso de la nueva clase media, se conjugan para cambiar el régimen.

La sociedad española cambia tanto a finales de los años sesenta que a finales de la dictadura franquista no sólo los españoles no tienen la oportunidad de crear un nuevo sistema de partidos políticos sino que cualquier intento en este sentido parece inútil. No sirve para nada proponer soluciones según las recetas de los períodos anteriores con partidos de masas clásicos o confesionales, porque la estructura de la sociedad española requiere otra cosa y el régimen en su autodisolución a partir de 1976 -que engendra tantas esperanzas como frustraciones- se acoge a la tradición monárquica mientras la sociedad apuesta por su democratización. La oposición en su conjunto no contaba con la fuerza social hegemónica suficiente para hacer caer la dictadura. Sólo le faltaba convencerse de

67 Juan Francisco Fuentes, art. citado, p. 31-32.

68 Antonio Elorza, « Primera Asamblea de intelectuales. Cultura : se inicia el parto ", Cuadernos para el Diálogo, $\mathrm{n}^{\circ} 196,4$ de febrero de 1977, p. 27.

69 Manuel Vicent, «La utopia concreta », Crónicas parlamentarias. 1977-1978, Madrid, Ed. Libertarias, 1984, p. 121. 
que monarquía y democracia no eran incompatibles. Ésta será la tarea de los movimientos constituidos, la Plataforma y la Junta democrática que acabarán uniéndose ${ }^{70}$.

El PSOE empezaba a reorganizarse fuera antes del congreso de Suresnes que vio su dirección de militantes exiliados sustituida por jóvenes de dentro formados más que en la lucha revolucionaria en la democracia cristiana de Manuel Giménez Fernández ${ }^{71}$ de Joaquín Ruiz Giménez. Pasó lo mismo en el seno del PCE, el gran partido del interior, cuando Santiago Carrillo propuso una vía europea del comunismo que rompiese con la URSS provocó una escisión liderada por Enrique Lister. En 1948 el PCE se decide por una lucha pacífica de masas, pero no condena el terrorismo inicial de ETA (el único residuo del franquismo es ETA militar).

Antifranquistas liberales, demócratas cristianos, liberales a secas, socialistas históricos, socialistas de Suresnes y socialistas rupturistas convergieron pues en la necesidad de superar el pasado, de "convertirlo en historia», según decía Tierno, y el empeño por recuperar la cultura liberal ${ }^{72}$. Pero para reconstruir una comunidad moral no se podía obviar la herencia política del exilio ${ }^{73}$.

\section{El legado del exilio}

La otra necesidad era conectar con las mayores figuras del exilio republicano. Pero si hubo una inserción metodológica del exilio en el discurso histórico, ésta se tradujo por un escaso impacto de sus exponentes en las políticas de la Transición.

Fue el exilio de todo un pueblo con representantes de todas las clases sociales y entre ellos unos cinco mil intelectuales. Carlos Blanco Aguinaga añadiría más tarde: «Toda una generación de miles de "hispano-mexicanos" que, habiéndose mexicanizado pronto sin olvidar su infancia española, nunca han sido del todo ni españoles ni mexicanos. Así es que lo mío, como los de mis compañeros de generación de México, ha sido y es el limbo histórico» ${ }^{74}$. El tiempo había hecho su obra y si el franquismo no había desarraigado del todo a la «Anti-España roja» muchos repetian con Víctor Alba: «Nuestra emigración se ha convertido, querámoslo o no, en un limbo político ${ }^{75}$. En cuanto a Luis Araquistáin, había puesto en guardia, en el otoño de 1955, contra un optimismo excesivo, como fue el de Álvaro de Albornoz cuando auguraba, en 1946, una pronta desaparición del franquismo ${ }^{76}$ : «No tenemos ninguna influencia positiva sobre lo que acontece en España y en el mundo en

70 « Sobre la Junta Democrática Española », Boletín de la Organización Unitaria del PCE en México, $\mathrm{n}^{\circ}$ 6, septiembre 1974, pp. 1-4. Se puede consultar en la Fundación Pablo Iglesias, Sig. P. 488.

71 Javier Tusell, Historia de la Democracia cristiana, 2 vols., Madrid, Edicusa, 1974

72 Voluntad simbolizada por la lectura de cuatro tesis dirigidas por Elias Diaz, a principios de los años setenta: las de Emilio Lamo de Espinosa, Filosofia y politica en Julián Besteiro, Madrid, Cuadernos para el Diálogo, 1973, 387 p.; Francisco J. LAPORTA Adolfo Posada: Politica y sociología en la crisis del liberalismo español, Madrid, Cuadernos para el Diálogo, 1974, 355 p.; Virgilio Zapatero, Fernando de los Rios: los problemas del socialismo democrático, Madrid, Cuadernos para el Diálogo, 1974, 286 p. y Manuel NúNez ENCABo, Sales y Ferré: los origenes de la sociologia en España, Madrid, Cuadernos para el Diálogo, 1976, 397 p.

73 Elias DiAz, «Las ideologias de (sobre) la Transición», en José Félix Tezanos, Ramón Cotarelo y Andrés de Blas (eds.), La Transición democrática española, Madrid, ed. Sistema, p. 757-784.

74 Carlos Blanco Aguinaga, De mal asiento, Barcelona, Caballo de Troya, 2010, p. 321.

75 Victor AlBa, prólogo a Fidel Miró, ¿Y España, cuándo ? (El fracaso político de una emigración), México, Libro Mex, 1959, 238 p. Citado en José Luis Abellan (dir.), El exilio español de 1939, Madrid, Taurus, 1978.

76 «No parece que aquel régimen pueda durar mucho tiempo aủn », escribía en 1946 a su familia (cortesía de Aurora de Albornoz). 
sus relaciones con el problema español. Somos espectadores de la historia, hemos dejado de ser actores. Somos una fuerza negativa, de repulsión, de exclusión. Somos una admirable Numancia errante que prefiere morir gradualmente a darse por vencida». ${ }^{77}$

La Guerra civil cambia la naturaleza del compromiso de los intelectuales. Los que se niegan a transformarse en militantes al servicio de uno de ambos campos toman el camino del exilio. Pronto comprueban que se condenan al olvido si pierden el contacto con los intelectuales del interior. Cuando pueden volver, a algunos les duele que España haya podido seguir funcionando sin ellos, otros comentan lo mortífero que fue el exilio: «el escritor trasterrado sólo tiene dos caminos, o quedarse en el idioma de su época (cada época tiene su idioma, como cada país), parar el reloj del estilo en la hora de partida, o adoptar el idioma del nuevo país (en América se habla español, pero no castellano). Así, unos nos resultaban arcaicos y otros extranjeros» ${ }^{78}$.

Sin embargo, desde mediados de la década de los noventa, el exilio se había convertido en una verdadera cuestión de Estado, en un grado muy superior al antifranquismo clandestino, asociado con la lucha del PCE cuya dirección no había renunciado a la tesis de la huelga general para acabar con la dictadura. Se celebró el exilio, más vinculado a los socialistas, en virtud de su presencia internacional y su capacidad de denuncia del régimen franquista en el exterior del país. En este uso público, que tanto consenso suscitaba, prevaleció la recuperación intelectual menos problemática de la figura de los literatos frente a las aristas políticas personales de ex protagonistas republicanos cuyo encaje sería conflictivo ${ }^{79}$.

Al compartir la convicción de que el final de la vida del dictador marcaría una oportunidad de cambio, los exiliados habían considerado que ellos representaban la memoria de la democracia y, por consiguiente, la democracia a secas y que les tocaba desempeñar un papel relevante en la organización de la nueva democracia aunque carecían de unidad ideológica y estrategia común. Incluso algunos estaban envueltos en la curiosa lógica del resentimiento. «A los retornados parecía dolerles secretamente que España hubiera seguido funcionando sin ellos, que España siguiera siendo muy española, pero a la hora del mundo, al margen de Franco y al margen de ellos mismos», apunta Francisco Umbral ${ }^{80}$, quien cita también

77 Carta citada por Xavier Flores, « El exilio y España », Horizonte español 1966, II, París, Ruedo Ibérico, 1967. En 2010, Carlos Blanco Aguinaga recordaba: «En cuanto a los de mi generación, a menudo llamada generación "hispano-mexicana", casi no ha vuelto ninguno. Excepciones serian, por ejemplo, Elena Aub, que volvió de México y Cuba, o Claudio Guillén, quien volvió de los Estados Unidos y que no mucho antes de morir en Madrid llegó a ser académico de la lengua española. O Tomás Segovia, quien sigue viviendo entre México y Madrid. Los demás siguieron en México (Ramón Xirau, Pascual Buxó, Arturo Souto, José de la Colina, la pintora Lucinda Urrusti, Federico Patán...) o en Estados Unidos (Roberto Ruiz, Manolo Durán, quien esto escribe...) o en Italia (Enrique de Rivas). Y no pocos han ido con los años muriendo en México (Luis Rius, José Miguel García Ascot, César Rodríguez Chicharro, Benito Messeguer, José Luis Benlliure...). Pero tampoco con los de nuestra generación se trata sólo de intelectuales y escritores o pintores. En México han seguido viviendo y muriendo abogados, ingenieros, doctores, editores y/o profesores de nuestra generación, más miles de otros refugiados, no pocos compañeros de colegio, dedicados a tareas tan comunes y corrientes como trabajar en empresas o montar negocios. Toda una generación de miles de "hispano-mexicanos" que, habiéndose mexicanizado pronto sin olvidar su infancia española, nunca han sido del todo ni españoles ni mexicanos. Así es que lo mío, como los de mis compañeros de generación de México, ha sido y es el limbo histórico.» (Carlos Blanco Aguinaga, De mal asiento, Barcelona, Caballo de Troya, 2010, p. 318-321).

78 Francisco Umbral, Y Tierno Galván ..., op, cit., p. 93.

79 Abdón Mateos, «El uso público del antifranquismo y del exilio después de Franco», Alcores, 2011, n 11, p. 21 .

80 Francisco Umbral, Y Tierno Galván ..., op. cit, p. 92. 
anónimamente el rencor de un escritor «muy de izquierdas» que le dijo: «Ellos han gozado la gloria y el mimo del exilio y nosotros nos tuvimos que quedar aquí barriéndoles la casa $»^{81}$.

La perspectiva de la relación con el interior, que examina los frutos políticos o culturales del exilio, ha sido la más explotada por los investigadores. Pero se enfrentaron a la dificultosa recepción de las obras exiliadas durante el franquismo y a su progresiva erosión vital o pragmática, hasta el estilo del escritor trasterrado pareció arcaico, como si se le hubiera parado el reloj, insinuaron algunos antifranquistas. Pasó lo mismo cuando algunos, como Manuel Andújar, regresaron para contribuir humildemente a la formación de una cultura nueva y fueron metafísicos pero no vehementes ${ }^{82}$. En general, estos intelectuales fueron más mentores que actores e incluso más moralistas, aferrados a la interpretación del presente, que ideólogos con visión de futuro. Sólo poblaron las páginas de los suplementos literarios de los diarios. Pero, antes de ir a Palacio recibidos por el Rey demócrata, consideraron que su país estaba ocupado por los fascistas.

Los retornos, en su mayoría fueron dolorosos en la medida en qué era difícil reencontrarse con un mundo que había dejado de existir y una sociedad que había procurado olvidar este episodio. Algunos habían vuelto solapadamente, casi a hurtadillas como Alejandro Casona o Corpus Barga («Aquí no lo conocía nadie, ni siquiera la censura», dijo entonces Umbral $^{83}$ ). Otros seguían regresando de vez en cuando silenciosamente como Jorge Guillén, o se quedaron muy poco como Eduardo Zamacois o Max Aub quien sólo pudo comprobar que ya no le conocían o, lo que era peor, que hasta el librero de Valencia le había olvidado ${ }^{84}$. «Volver no es estar de vuelta», sentenciaría Aub. Parecido aforismo acompaña también el regreso de los EE UU de Aranguren, en 1976, cuando confiesa una influencia marxista y comprueba que en su facultad se hallaría ahora en la extrema izquierda ${ }^{85}$. Entonces empieza a referirse a una contracultura y reivindica la democracia y la postmodernidad ${ }^{86}$. Está muy lejos de la cultura del exilio cuyo reencuentro se estrella pues sobre un anacronismo que ningún método puede superar.

Sin embargo, las organizaciones políticas en el exilio cobran mayor fuerza a principios de los años setenta ${ }^{87}$. Les toca entender que no pueden pretender representar exclusivamente la voz de la España democrática y que tienen que lograr mayor unidad y aproximarse a la oposición interior. Sólo Acción Republicana Democrática Española (ARDE), que agrupaba desde 1960 los partidos republicanos liberales, era favorable al mantenimiento de las instituciones republicanas en París, una opción con la que habían roto, desde finales de los años cuarenta, los socialistas y los comunistas ${ }^{88}$. Cuando murió Martínez Barrio, el $1^{\circ}$ de enero de 1962, asumió el cargo de presidente de la República en el exilio Luis Jiménez de Asúa, quien nombró presidente del Gobierno a Claudio Sánchez Albornoz. Pero ya

81 Ibid., p. 93.

82 Paul Aubert, Volver : el lugar de Mamuel Andújar en la poesía del exilio, Jaén, Diputación de Jaén, 2013.

83 Francisco Umbral, Y Tierno Galván ..., op. cit, p. 89.

84 Max Aub, La gallina ciega, México, Joaquín Mortiz, 1969.

85 Entrevista por M.B., Cuadernos para el Diálogo, n $179,2-8$ octubre de 1976 , p. 53-55; $A B C, 16$ de diciembre de 1976.

86 José Luis López Aranguren, Moral de la vida cotidiana, personal y religiosa, Madrid, Tecnos, 1987, p. 168.

87 Jorge DE Hoyos PueNTE, « Pensando en el regreso. Las organizaciones políticas del exilio republicano en México frente al ocaso franquista y la Transición española », Historia Social, n74, 2012, p. 85-101.

88 Juan Antonio Andrade Blanco, El PCE y el PSOE en la Transición. La evolución ideológica de la izquierda durante el proceso de cambio politico, Madrid, Siglo XXI, 2012. 
estas instituciones iban perdiendo representatividad, pues carecían del apoyo de los demás grupos políticos y de los sindicatos. Esta marginación, y la lucha en el seno de los antiguos partidos entre históricos y renovadores, acabaron con la muerte del dictador que les llevó a adoptar una actitud posibilista aunque con estrategias diferentes. Las tensiones provocadas por la llegada a la dirección del PSOE de los jóvenes (Felipe González, Alfonso Guerra, Guillermo Galeote etc.) en el congreso de Suresnes en 1974 y las tesis eurocomunistas de Santiago Carrillo tuvieron como consecuencia una pérdida de influencia mientras los republicanos de ARDE apoyados por el presidente mexicano, Luis Echevarría, se veían excluidos del proceso electoral de 1977. Denunciaban la solución monárquica como un engranaje de la dictadura, mantenían la necesidad de conocer mediante referéndum la voluntad popular acerca de la forma del futuro gobierno de España y preconizaban una ruptura con los poderes políticos y económicos del franquismo. Exigían asimismo una evaluación de las fortunas constituidas durante la dictadura por la élite empresarial que explotó la red vertical corporativa del régimen. También se opusieron a la amnistía como recurso jurídico para liberar a los presos políticos, pues lo consideraban una ofensa pues no se sentían culpables. Además dicha modalidad también impedía la investigación de los crímenes del franquismo y sobre todo creaba una analogía entre verdugos y víctimas ${ }^{89}$.

Temían que se instrumentalizara la vuelta de los dirigentes de los partidos en el exilio. De hecho, se celebró, en abril de 1976, la vuelta de Salvador de Madariaga, quien leyó su discurso de ingreso en la Real Academia de la Lengua en la que fue elegido el 20 de mayo de 1936, y la del último presidente del gobierno en el exilio, el historiador Claudio Sánchez Albornoz (aunque ésta sería definitiva en julio de 1983), al mismo tiempo que se tergiversaban sus posiciones políticas. Tampoco pudieron los republicanos de ARDE presentar candidatos en las elecciones (sólo obtuvieron su legalización en agosto de $1977^{90}$ ) ni, por consiguiente, defender su modelo para la España democrática participando en las Cortes constituyentes, mientras se legalizaba al PCE, el 9 de abril de 1977. Rodolfo Llopis, ex secretario general del PSOE, llegó a Barcelona el 16 de enero de 1976. Tras el fracaso de su candidatura a un puesto de senador por Alicante, regresó a Francia.

Algunos de estos intelectuales desterrados habían desempeñado carteras en los gobiernos del exilio. Victoria Kent vivió cuarenta años en Nueva York dedicada exclusivamente a la vida política española, y dirigió una publicación, Ibérica por la Libertad ${ }^{91}$. Otro militante de Izquierda Republicana, el químico Francisco Giral, muy activo dentro de ARDE (fue ministro en el último gobierno de la República en el exilio) también preparaba el regreso a una España democrática, hasta fundar una revista en noviembre de 1974 en México, titulada República Española, cuando Victoria Kent cerraba la suya. Giral quería participar en el proceso transitorio y concebía ARDE como el gran partido republicano de la futura democracia española ${ }^{92}$. Victoria Kent no estaba dispuesta a volver a España para compartir la suerte de Claudio Sánchez Albornoz, recibido por fotógrafos pero sin discursos ni

89 En 2004, el día de la Fiesta nacional, el Ministro de Defensa, José Bono, reservó el mismo trato a un soldado republicano y a un miembro de la División Azul.

90 Alicia AltED, « La oposición republicana, 1939-1977) », Nigel Towson (ed.), El republicanismo en España (1830-1977), Madrid, Alianza ed., 1994, p. 223-262.

$91 \mathrm{M}^{\mathrm{a}}$ Dolores Ramos, Victoria Kent (1892-1987), Madrid, Ediciones del Orto, 1999 ; Miguel Ángel Villena, Victoria Kent. Una pasión republicana, Madrid, Debate, 2007.

92 «Nuestras razones », Ibérica por la Libertad, Nueva York, vol. 22, n¹2, 15 de diciembre de 1974, p. 9. 
homenajes políticos ${ }^{93}$. Francisco Giral, hijo de José Giral que fue presidente del Gobierno de la República del 19 de julio al 4 de septiembre de 1936, regresó brevemente en septiembre de 1976 dispuesto a desempeñar un papel político, anunciando que los republicanos acatarían la decisión libremente expuesta del pueblo español ${ }^{94}$. Volvió el 9 de abril de 1977 y fue detenido sin duda porque el gobierno quería impedir una conmemoración de la proclamación de la II República. Luego fue readmitido, como Arturo Pérez Vitoria, en el cuerpo de catedráticos españoles ${ }^{95}$, y recobró su cátedra de Química orgánica en la universidad de Salamanca. Después de la celebración de las elecciones a las Cortes constituyentes y de la disolución de las instituciones republicanas en el exilio, se legalizó a ARDE y Francisco Giral fue elegido presidente ${ }^{96}$. Entonces Victoria Kent regresó el 11 de octubre de 1977 pero su militantismo republicano y su antifascismo parecieron anacrónicos. La candidatura de Giral a la rectoría de la Universidad de Salamanca fue vetada por el Ministerio de Educación.

Sólo les quedó, como a otras figuras republicanas participar en algunos debates televisivos antes de volver a Nueva York, en el caso de Victoria Kent o, a lo que a Giral se refiere, a jubilarse tras haber reiterado los principios de una república ideal, los de Giner de los Ríos, que habían quedado desterrados y que suscitaban poco interés en la España de la Transición ${ }^{97}$, o confiado todavía, como el penalista Mariano Ruiz Funes, muerto en el exilio mexicano en 1953, en el valor genérico de la libertad para alcanzar la concordia y el progreso ${ }^{98}$. Giral confesó que se sentía ahora, en un país que estaba muy lejos del que habían tratado de construir, y que vivía un segundo exilio, dentro de España ${ }^{99}$. Y acabó regresando a México. La ceremonia que había imaginado para celebrar la continuidad de España, se frustró: «El día que haya unas elecciones abiertas, el Gobierno republicano regresará a España y entregará la legitimidad. Entonces se volverá a incorporar a la historia de España y se cerrará definitivamente un ciclo histórico» ${ }^{100}$. Pero tras las elecciones de junio de 1977, en las que los partidos republicanos del exilio no pudieron participar, los últimos presidentes del Gobierno, Fernando Valera y de la República, José Maldonado, disolvieron las instituciones republicanas en París el 21 de junio de $1977^{101}$. La exclusión del republicanismo histórico, mientras los ex ministros y dirigentes del franquismo implicados directamente en episodios de represión se convertían en padres de la patria democrática, supuso la ruptura definitiva con el legado de la Segunda República.

93 José F. BeAumont, « No volveré a España mientras no exista auténtica libertad », El País, 11 de junio de 1976.

94 Francisco Giral, «La posición republicana », El País, 26 de septiembre de 1976.

95 Yolanda Blasco Gil y Tomás Saorin Pérez, Las universidades de Mariano Ruiz-Funes. La lucha desde el exilio por la universidad perdida, Murcia, Universidad de Murcia-Editum, 2013, 466 p.

96 «Se celebró en Madrid el Congreso Nacional de ARDE», en República española, año IV, n 58, 30 de septiembre de 1977 , pág. 1.

97 Luis Méndez Asensio, «Francisco Giral. Pasado y presente de la República », Tiempo de Historia, $\mathrm{n}^{\circ}$ 62 , enero de 1980 , p. $4-15$.

98 A. Alted Vigil, La voz de los vencidos. El exilio republicano de 1939, Madrid, Aguilar, 2005; A. MAteos, « Los republicanos españoles en el México cardenista », Ayer, n47, Los exilios en la España contemporánea, 2002, p. 103-128.

99 El Archivo de la Palabra. Entrevista a Francisco Giral por Elena Aub, Salamanca, 1981. INAH, Libro 51. $\mathrm{PHO} / 10 / 27$, p. 328 y ss.

100 El País, Madrid, 16 de junio de 1976.

101 Aunque los políticos que estaban llevando a cabo la Transición no reconocieron la República en el exilio, el Archivo del Gobierno de la República en el exilio fue entregado a la Fundación universitaria española dirigida por el ex ministro de Franco y monárquico, Pedro Sainz Rodríguez. 
Otra consecuencia fue una recuperación incompleta del exilio en la memoria y la historiografia española. Pues la cultura del exilio acabó siendo un peso muerto de la Historia, porque no hubo fusión con la cultura democrática. Los designios de Sánchez Albornoz se frustraron y finalmente fue Josep Taradellas, el presidente de la Generalitat en el exilio, que reconoció a la Monarquía, el único político del exilio quien tuvo un protagonismo en la Transición. El lehendakari Jesús María de Leizaola, regresaría más tarde, el 15 de diciembre de 1979. Con ello se cerraba un periodo de 43 años de exilio de una institución republicana elegida democráticamente en octubre de $1936^{102}$.

El exilio, los intelectuales lo vivieron inicialmente como un «tránsito», una Transición, para quienes no tardarían en regresar: « Retorno de lo vivo lejano», decía Alberti. Pero el proceso de reconstrucción moral no fue posible, pues el país dejado había cambiado. Los intelectuales habían regresado paulatinamente: el escritor Antonio Sánchez Barbudo en 1959, el poeta Manuel Altolaguirre, Alejandro Casona, en 1962. También volvió Rosa Chacel en 1971; Ernestina de Champourcín, viuda de Juan José Domenchina, muerto en México en 1959. Todos entendieron que la condición de exiliado no se pierde nunca y que la ambición de tener algún peso en el proceso de la Transición a la democracia era una ilusión ${ }^{103}$. Como lo había sido la posibilidad de integrarse en la vida cultural del país hospitalario. Se crearon editoriales, desde Séneca de Bergamín, o el Fondo de Cultura Económica (tras una transcripción errónea y apresurada de Ecuménica, explicó algún protagonista) en México, Ruedo Ibérico, en París, en 1961. Pero no se integraron plenamente a la vida cultural del país de acogida, pues fueron siempre editoriales... del exilio.

El 20 de noviembre de 1984, cuando regresaba desde Ginebra a Madrid, a los 80 años, María Zambrano, algunos periodistas consideraron que después de la vuelta de Rafael Alberti, de Ramón J. Sender y de Jorge Guillén y otros se acababa el exilio republicano ${ }^{104}$, mientras Juan Marichal recordaba la existencia de « unos centenares exiliados humildes $[\ldots]$ y de muchos compatriotas gloriosos».

\section{Integración en la España democrática}

Sin establecer una tipología del intelectual opuesto al régimen de Franco, se pueden contrastar varios itinerarios y comprobar convergencias.

Los exiliados no podían limitarse a revivir los tiempos pasados y algunos procuraron pensar los nuevos. También se alza, tras la de tantos, la voz original de Manuel Andújar que quiso volver no como héroe sino como poeta sereno capaz de superar -no de olvidarla circunstancia y escribe su obra poética cuando ya está de nuevo en España donde se contenta con la eficacia de una labor editorial discreta ${ }^{105}$. Hubo también otros exiliados, los que no se habian integrado del todo en la nueva España, a quienes les disgustaba el cariz

102 J. Angulo, « Jesús María de Leizaola vuelve a Euskadi tras 43 años de exilio », El Pais, Madrid, 15 de diciembre de 1979.

103 Un decreto del gobierno de Arias Navarro del 22 de noviembre de 1975, concedía un indulto general, excepto para los delitos de terrorismo, cuando gran parte de la opinión pensaba que la reconciliación pasaba por una amnistía que llegó el 30 de julio de 1976 con un decreto-ley de Adolfo Suárez, ampliado por una ley aprobada por el Parlamento, el 15 de octubre de 1977.

104 El 20 de noviembre un titular del diario El País anunciaba : « Con el retorno a España de la escritora Maria Zambrano finaliza el exilio español de 1939 »

105 Manuel Andújar es con Rafael Alberti, Jorge Guillén, José Bergamín algunos de los pocos que regresaron a España. Su retorno fue sin duda el más discreto. A su manera, Alberti triunfó, presidió la sesión inaugural de las Cortes en 1977. Recibió el premio Cervantes y homenajes por doquier. 
que tomaba la Transición, y continuaron mirando hacia una España republicana idealizada. Una recuperación atomizada de las figuras del exilio se llevó a cabo por el intermediario de algunas fundaciones ${ }^{106}$. Pues aunque estas iniciativas favorecieron la recuperación y preservación del patrimonio o el fomento y difusión del saber social sobre el exilio, insistieron en la vinculación geográfica del intelectual en cuestión con su región de origen, e institucionalizaron al exiliado de turno según referencias cultura alejadas de lo político.

Pocos logran como Francisco Ayala una integración en la España democrática. El escritor se carteaba con intelectuales del interior: Dionisio Ridruejo, José Luis López Aranguren, Camilo José Cela o Pedro Laín Entralgo, entre otros. Estaba vinculado al grupo de Burgos de los falangistas «liberales» críticos con la actuación de Franco tras la guerra. «Yo nunca me negué al contacto con escritores o con personas de tipo intelectual de España. [...] Aunque fueran de derechas [...] porque una de las cosas más terribles que han ocurrido, más devastadoras, con esto de la guerra civil, es la polarización artificial », explicó ${ }^{107}$. Sin embargo, tras cada viaje, como describe en su ensayo España a la fecha (1965), obra censurada hasta 1977, Ayala se iba convenciendo de que el proceso de una Transición política hacia el régimen democrático se desarrollaría sin grandes perturbaciones ${ }^{108}$. Tal certidumbre le venía del examen del contexto europeo. Pues comprobaba Ayala que el crecimiento del que se beneficiaba Europa tenía que acabar contagiando a la sociedad española. Los efectos del capitalismo agresivo de la segunda mitad del siglo XX no se circunscribían a la estructura económica del país sino que su ola expansiva llegaba hasta la esfera social.

Buena parte de la oposición al régimen franquista, tanto dentro como fuera de España, no aceptó el pragmatismo de Ayala quien se negó a aplicar cualquier tipo de interpretación marxista ${ }^{109}$ a los acontecimientos en curso y descartó la posibilidad de una ruptura brutal con el franquismo ${ }^{110}$. Pero necesitaba estar presente física y moralmente en España. Por eso, Ayala decidió regresar antes que muchos otros exiliados. Aspiraba a poner las bases para la creación de una red de relaciones culturales, ideológicamente pacificadas, entre quienes vivían en España y quienes estaban en el exilio: exiliados de filiación liberal, socialdemócratas opuestos al régimen, jóvenes cosmopolitas deseosos de normalidad política, falangistas convertidos en antifranquistas etc.

La primera entrevista de Ayala en un periódico español tuvo lugar en verano de 1969. Se titulaba, «Un exiliado sin ira», reflejaba el clima cultural que se estaba imponiendo en

106 Ejemplos de ello, entresacados del mundo de la literatura y el arte, son la Fundación María Zambrano en Vélez Málaga fundada en 1987 que se dota en 2003 de un Centro de Estudios sobre el Exilio. La Fundación Rafael Alberti en el Puerto de Santa María, Cádiz, en 1993, que en su presentación enfatiza la relación de Alberti con la poesía y la generación del 27 , pero no con el exilio, algo muy parecido a lo que sucede con la Fundación Jorge Guillén en Valladolid creada en 1992; la Fundación Max Aub, creada en 1997, ya con el PP en el poder; la Fundación Ramón J. Sender en Huesca, creada en 1983; la Fundación Eugenio Granell en Santiago de Compostela, creada en 1995 y la Fundación Zenobia Juan Ramón Jiménez, creada en 1987 en Palos de Moguer, Huelva.

107 Archivo Fundación Francisco Ayala, Entrevista a Francisco Ayala realizada por Elena Aub en Madrid los dias 22, 23, y 24 de julio de 1981. Y anexo realizado el dia 27 de enero de 1982, p. 96.

108 Francisco AyalA, España y la cultura germánica. España, a la fecha, en Francisco AyalA, Ensayos políticos y sociológicos, Galaxia Gutenberg, Barcelona, 2007, p. 1052.

109 Según el testimonio de Manuel Tuñón de Lara, que fue su alumno en la clase de Derecho politico, en la facultad de Derecho de Madrid, cuando le tocó sustituir a Manuel Garcia Pelayo, era evidente que no sabia gran cosa del marxismo.

110 Véase la entrevista: Javier GoÑı, «El nacionalismo es un instrumento de poder», El Pais, 12 de agosto de 1992, p. 10. 
las instituciones oficiales ${ }^{111}$. Desde la concesión del Premio de la Crítica de Narrativa, en 1972, a su obra El Jardín de las delicias, la reintegración de Ayala en el seno de la cultura española se estaba produciendo mucho antes que la del resto de los exiliados. La Guerra Civil, en opinión del escritor, no había sido más que uno de los muchos levantamientos que caracterizaban la historia de España. De manera que lo que a Ayala le interesaba del conflicto como escritor y sociólogo era la reacción posterior de la intelectualidad.

En mayo de 1983, Francisco Umbral, uno de los narradores más cáusticos de la Transición, describía su propia amargura ante un proceso de democratización cultural que no había desembocado en una nueva edad de oro para España. El periodista acusaba también al exilio intelectual, cuyos miembros, una vez regresados, no habían sabido renovarse, ni aportar a nivel ideológico ningún pensamiento nuevo en beneficio de la democracia. Cuando Ayala le conminó a explicarse en una carta por semejante juicio aparentemente tan descarnado, Umbral le contestó:

«Amigo Ayala: (...) Ocurre que Uds., los exiliados, fueron nuestra España viva, actual, verdadera, durante los 40/40, frente a la España convencional que nos ofrecía el franquismo. Cuando Vds. empezaron a volver, y sobre todo, ya en la democracia, me ha sorprendido que el exilio/retorno casi en bloque (...) se mantiene como al margen de la política/vida nacional, (...) moviéndose siempre en cielos de cultura o tomando los problemas desde muy arriba $(\ldots)\rangle^{112}$,

Las palabras de Umbral eran el análisis de una actitud apolítica presente en algunos de los exiliados republicanos que volvieron a España durante la Transición. Para el periodista, ésta demostraba su dificultad para integrarse en la nueva España. En otro tiempo, habían representado a la España «(viva»; ahora se limitaban a participar en la vida pública desde un enfoque cultural. Pero Ayala se expresó en los medios más conocidos y de mayor tirada, y, al mismo tiempo, presentó la Segunda República como un período complejo, en particular en los retratos de los principales actores (Azaña o Luis Jiménez Asúa) que publicó en la prensa. En cambio, decidió no usar políticamente su antigua militancia republicana, para respetar la autonomía de las esferas política y cultural ${ }^{113}$. Por lo tanto, el aparente desinterés político del escritor granadino no fue un fin en sí mismo ni el fruto del trauma causado por el exilio. Había en este distanciamiento un enfoque institucionista u orteguiano.

Mirar al pasado para intentar reubicarlo en el presente representa para Ayala una mera ilusión. Convencido de que no se puede actualizarlo políticamente, tras su retorno, reflexiona sobre el futuro del país, así como sobre los comportamientos y valores contemporáneos tanto de España como de las grandes potencias internacionales. Se interesa por el comportamiento de nuevos ricos de los españoles, las buenas perspectivas de un ingreso en la CEE y el final de la leyenda negra ibérica. La utilización política de los exiliados no le interesa en absoluto. Ayala se convierte en uno de los exiliados que alimentaron la cultura política de la reconciliación, el pacto y el reformismo pacificador ${ }^{114}$. Durante la década de los ochenta Ayala aunaba capacidad crítica, negación del modelo de intelectual comunista, espíritu ilustrado, defensa de la razón y voluntad de diálogo democrático con todas las instancias de la nueva España posfranquista. Se convirtió en un cronista de la Transición,

111 Miguel Fernández Braso, «Francisco Ayala, exiliado sin ira», Pueblo, 25 de junio, 1969.

112 Archivo de la Fundación Francisco Ayala, Carta de Francisco Umbral a Francisco Ayala (Madrid. 1983).

113 Cfr. Santos Julia, Francisco Ayala, escritor público, en Francisco Ayala, De vuelta a casa. Obras completas VI, op. cit., pp. 17-44.

114 Francisco Ayala, Recuerdos y olvidos, Madrid, Alianza ed., 1988, p. 501. 
que condenó, desde la tribuna que le ofrecían los periódicos, la desilusión o el desencanto que se apoderaba entonces del pensamiento de la mayoría de intelectuales españoles ${ }^{115}$.

Parece claro, por todo lo enumerado hasta ahora, que República y exilio juegan un papel significativo en la construcción simbólica, liderada desde el poder socialista, de una genealogía moderna y europeizante para la España de los años 80, que no altera de manera significativa la línea marcada por los gobiernos de la UCD en la Transición. Pero se trata de una recuperación asimétrica, que enfatiza la vuelta del comunista-demócrata Alberti y la del excomunista-anticomunista Semprún atraído por posturas liberales, y olvida el legado político del republicanismo exiliado. Jorge Semprún rompe la linearidad cronológica, lo revuelve todo y consigue entre testimonios y recuerdos, olvidos y reiteraciones, construir, desde la autobiografía y un vaivén entre militancia y literatura, un incuestionable laberinto heroico capaz de borrar contradicciones entre la ortodoxia del dirigente político y la libertad del intelectual ${ }^{116}$.

Desde la polémica suscitada por la publicación de Autobiografia de Federico Sánchez a finales de 1977 que explica el viraje de Jorge Semprún, tras su expulsión del PCE, en la reunión celebrada en el castillo de Zbraslav en Praga, junto con Fernando Claudín, y Francesc Vicens en 1964 -coincide también con el alejamiento de Jordi Solé Tura-y la inquina de Pasionaria contra estos «intelectuales con cabeza de chorlito» ${ }^{117}$, un grupo va buscando, fuera del partido, el comunismo ideal contra el eurocomunismo propugnado por Santiago Carrillo tras la condena de la intervención soviética en Checoslavia ${ }^{118}$. Los reproches de Semprún no fueron compartidos por todos los militantes críticos con el PCE que, como Javier Pradera y Fernando Claudín, se acercaron también a la socialdemocracia a finales de los años setenta ${ }^{119}$, pues aparecía como juez y parte. La denuncia de las carencias organizativas y del funcionamiento no democrático del partido lo retrotraía a los tiempos del dogmatismo estalinista. Y la generación que había sido comunista a partir de los años treinta, para luchar contra el arraigo del fascismo, experimentaba un sentimiento de desánimo o flojedad ideológica. Además, el PCE, que pensaba absorber el electorado socialista, estuvo debilitado por su fracaso electoral.

A partir de los años setenta, aparecen autobiografias y memorias, de políticos y de intelectuales. Pedro Laín Entralgo, un falangista convencido que apoyó el bando rebelde durante la Guerra civil, desempeñó un papel político y cultural en la España franquista (dirigiendo, por ejemplo, la Editora Nacional), quien publica su Descargo de conciencia 1930-1960 en abril de 1976 en plena Transición democrática. El relato autobiográfico cobra la forma de un mea culpa, de un ajuste de cuentas consigo mismo, con capítulos dotados de epílogos autocríticos que no dejaron de irritar a quienes esperaban menos rodeos y una palabra más nítida. Esta obra hace eco a otras memorias como Casi unas memorias de Dionisio Ridruejo, no sólo por la forma sino también por la polémica que ambas engendraron cuando su publicación. También se puede añadir Crítica y meditación y Memorias y esperanzas españolas de José Luis L. Aranguren.

115 Francisco Ayal.A, De vuelta a casa. Obras completas VI, Galaxia Gutenberg, Barcelona, 2013. Juan Pecourt, Los intelectuales y la Transición política, CIS, Madrid 2008, pp. 263-273.

116 Marta Ruiz GALBETE, Jorge Semprún : réécriture et mémoire idéologique, Tesis doctoral (P. Aubert, dir.), université de Provence, 2001.

117 Marta Ruiz GALBETE, «"Intelectuales con cabeza de chorlito" : Jorge Semprún contra el eurocarrillismo», Bulletin d'Histoire Contemporaine de l'Espagne, Aix-en-Provence, CNRS-UMR Telemme, n³0-31, junio 2000, p. 397.

118 Jorge Semprún, «El eurocomunismo está muerto », Cambio 16, $1^{\circ}$ de junio de 1980, p. 51.

119 Javier Pradera, « Las verdades parciales de Semprún », Cambio 16, 2-8 de enero de 1978. 
Los diversos estudios que han analizado el papel de la literatura autobiográfica durante la Transición atribuyen a estos autores la voluntad de describir una evolución ideológica que les permita integrarse en la nueva democracia española. En efecto, dicha literatura fue paralela a la que adquirió una relevancia singular para los intelectuales de la misma promoción que habían vivido la experiencia del exilio y el regreso ulterior a la patria. Fueron numerosos los exiliados que redactaron sus memorias o publicaron su propio diario, como Francisco Ayala, María Zambrano, Rosa Chacel, Rafael Alberti, Juan Gil Albert y Jorge Semprún. Simultáneamente, otras personalidades destacadas del campo cultural de los setenta y ochenta se dedicaron a la reconstrucción de su vida durante la dictadura: desde perspectivas muy diferentes, Carlos Barral, Juan Goytisolo, Fernando Savater José Manuel Caballero Bonald o Gonzalo Torrente Ballester ${ }^{120}$.

Al fin y al cabo, la autobiografía acaba convirtiéndose en una forma de lectura pública de la propia identidad ${ }^{121}$. En otras palabras, el intelectual que reconstruye su propio recorrido lo hace en un determinado momento histórico, condicionado por la propia imagen que tiene de sí mismo o de aquella que piensa que el público tiene de él. En el caso del exiliado Ayala, el momento histórico en cuestión es la nueva época constituyente que se abre en España, la Transición. La autobiografía ofrece la posibilidad de transformar un espacio privado en un espacio público. De hecho, el sujeto de las memorias de Ayala es también colectivo. Ahora bien, la diferencia del proyecto de Ayala con el resto de exiliados es el hecho de que se concibe como un acto cívico. Ayala quiere divulgar ahora, en la España de la Transición, el espíritu reformista de la época de su juventud ${ }^{122}$.

A finales del siglo XX, frente a una cultura occidental que parecía estar en vías de unificación, intuía el escritor que la propia noción de exilio tenía que ser desvalorizada con objeto de no crear nuevas categorías ideológicas artificiales como lo era la misma nación. Lo cual le condujo a reflexionar sobre el exilio en términos desmitificadores porque insistía en que «los que abandonamos España no fuimos más exiliados que los que quedaron» ${ }^{123}$.

Ideólogo falangista a partir de 1937, informante durante la Guerra civil y la postguerra ${ }^{124}$, creyente católico y valedor preconciliar de las reformas doctrinales de la Iglesia, Aranguren fue reconocido tras la restauración borbónica postfranquista como uno de los principales

120 José Nicolás Romera Castullo, Literatura autobiográfica en España: apuntes bibliográficos sobre los años ochenta, en Francisco Ernesto Puerta Moya, José Luis Pérez Pastor (coord.), El temblor oblicuo: panorama de escrituras autobiográficas, Universidad de La Rioja, Logroño, 2004, pp. 17-42.

121 Sylvia Molloy, At face value: Autobiographical Writing in Spanish America, Cambridge UP, Cambridge, 1991.

122 El 25 de noviembre de 1975, pocos días después de la muerte de Franco, las Cortes Españolas ratificaron su reincorporación de Ayala -aunque el escritor tenía todavía pasaporte estadounidense y no recibió el español hasta 1990 - a su puesto de Letrado de las Cortes, para que pudiese recibir la pensión.

123 Entrevista de Francisco Ayala por Martínez CARrILLo, «Los que abandonamos España no fuimos más exiliados que los que se quedaron", Información, 4 de octubre, 1977, p. 7.

124 En 1993 Aranguren reconoció, en la apacible tranquilidad de un curso de verano (fue noticia en $A B C$ y en Diario 16 de 21 de agosto de 1993, sin que sorprendiera mayormente que, terminada la guerra, se encargó de elaborar informes sobre intelectuales que todavía se encontraban en el extranjero y que pretendian retornar a Espana. En la postguerra era Aranguren «un feliz rentista, que vivía leyendo y escribiendo tranquilamente en su gran piso de la calle Velázquez», dejó escrito su amigo José María Valverde (y en el Anuario español del Gran Mundo, Madrid 1942, p. 379, figura «López Aranguren, José Luis. T. 55883, Velázquez 25»). En el verano de 1999, un comentario de Javier Marias, hijo de Julián Marías, ( El artículo más iluso », El País, 26 junio 1999) desató una polémica, en torno a « Aranguren como delator franquista », en la que intervinieron, Javier Muguerza, Mauro Armiño, Soledad Puértolas, Francisco Umbral, Gregorio Morán y Elias Díaz. Las principales intervenciones en el portal del «Hispanismo filosófico»: http://www.filosofia.org/bol/not/bn006.htm. 
referentes ideológicos de la socialdemocracia coronada. Hubiera podido ser -tras la desaparición de Unamuno y Ortega- el guía moral de la juventud intelectual. Se movía en el círculo falangista del que surgió la revista Escorial (con Pedro Laín Entralgo, Dionisio Ridruejo, Antonio Tovar, Gonzalo Torrente Ballester), colaborando con frecuencia en las revistas y periódicos oficiales: Vértice, Escorial, La Hora, Arriba, Arbor, Revista de Estudios Politicos, etc. Encarnaba la figura del intelectual inconformista, luchador por la libertad y los derechos humanos, atento a la incidencia política de la ética enfocada a menudo desde una crítica de la religión, y desde unos presupuestos kantianos. Había llegado a creer que la fraternidad en la revolución era la cumbre del ideal ético de la modernidad. Lo que entendía Aranguren, que había sido un joven católico molesto por el dogmatismo del catolicismo español, por moral social era «el estudio de los mores o formas de vida colectiva» ${ }^{125}$. Todavía queda por explicar hasta qué punto este librito triste titulado Moral y sociedad (la primera publicación de la nueva editorial Cuadernos para el Diálogo en 1966 con tres ediciones de 4000 ejemplares), que invitaba a volver a las raíces del liberalismo en España y a Jovellanos, se convirtió en una especie de libro rojo para una parte de la joven generación, cuando la Iglesia se enfrentaba a la temida crítica bíblica y al diálogo con los marxistas.

Era, como Laín Entralgo y Julián Marías (llegado de un horizonte muy distinto, el campo de los vencidos, el grupo de «epígonos» de Ortega y Zubiri, y a quien no dejaron de reprocharle su aproximación a Besteiro), un católico, que se expresaba con acentos «liberales» aun en materia religiosa. Le dolió el que ciertas obras de Unamuno estuvieran incluidas en el Índice. Luchó siempre por la libertad de cátedra, y defendió a Ortega de los recelos de algunos sectores de la extrema derecha. Aranguren se acercó al protestantismo, leyó tardíamente a los 45 años una tesis y sacó, en 1955 en la universidad Complutense, la cátedra de Ética y Sociología, que había sido la de García Morente.

Aranguren propuso, en los años sesenta, una superación de la filosofia moral definida como «sistematización general de las categorías o conceptos éticos [que] opera en planos de abstracción y universalidad», por el testimonio del «moralista, aplicándose ya a lo más particular y concreto, [que] alumbra nuevos modos de ser, penetra en la mudable vigencia y jerarquía de las virtudes [...] Podríamos decir que se orienta más directamente hacia lo social y práctico, hacia la mores... ${ }^{126}$. Estaba dispuesto a seguir encarnando la disidencia o la reserva de quien habla en nombre de un mundo distinto con este estilo que se había forjado en el antifranquismo, entre la exigencia de Kant y el rapapolvo de Julien Benda a los intelectuales «comprometidos» que se arriesgan a perder su dignidad en la batalla y renuncian a fiscalizar el poder que viene. Según Aranguren, el intelectual, que es la voz de los que no se expresan, debe interesarse por la política pero no intervenir en ella : «Interesarse por ella, desde luego, sí; intervenir, en modo alguno. Hasta cuando menos mala, la política es siempre una simplificación de la realidad, y el intelectual se debe a la verdad entera. » $[. .$.$] « Nunca se es más libre que cuando se lucha por la libertad». Esta$ frase da cuenta del carácter ambiguo del intelectual abocado a intervenir en la vida pública en nombre de una entidad mayor que la política: los grandes principios.

«-Hablo de situaciones de hecho. En los pueblos sajones, los intelectuales, bien que no dejen de ser respetados a distancia, forman como un grupo aparte, menos entretejido con la urdimbre social común. En nuestros pueblos, en cambio, sucede lo contrario. Precisamente entre nosotros el peligro está en que el intelectual se articule demasiado con

125 José Luis López Aranguren, Moral y sociedad, Madrid, Cuadernos para el Diálogo, 1966, p. 9.

126 «Aranguren», en Jorge MAÑACH, Visitas españolas, Revista de Occidente, Madrid 1960, p. 287-300, Ibid., p. 294. 
el resto de la sociedad, subordinándose a los intereses creados y, a veces, organizándose para aprovechar dentro de ella tales o cuales ventajas. Esto desvirtúa su misión esencial. El intelectual tiene que atender a lo social, s'engager, como dicen ahora los franceses; pero sin comprometer su independencia para juzgar, criticar, estimular. A la verdad sólo se la puede servir desde la libertad.» ${ }^{127}$

Un intelectual del interior que compartió liderazgo intelectual con Aranguren en los años sesenta, Enrique Tierno Galván, pasó de pensador helenista hermético a alcalde de Madrid hasta llegar a «representarse a sí mismo» ${ }^{128}$, en una utopía ilustrada que entretendría al pueblo madrileño. También se inventó una biografía que le llevó a reivindicar el socialismo revolucionario, cuando la Revista de Estudios Políticos, a la que se acercó en los años 40, distaba mucho de ser un refugio de liberales disconformes con el régimen y sus contactos posteriores con monárquicos y democristianos le llevaron a pasar de un regeneracionismo costista a la opción de la monarquía de Don Juan antes de convertirse, tras el episodio del PSP, en intelectual orgánico del PSOE ${ }^{129}$ cuando algunos veían en él un nuevo Azaña ${ }^{130}$.

Dionisio Ridruejo fue un demócrata convertido más discreto. Era consciente de «haber ganado la guerra y perdido la paz». Después de haber deseado la disolución de Falange, y la ampliación de las bases del régimen mediante un plebiscito popular, creyó que sería posible, tras un período constituyente, dar a las masas la oportunidad de organizarse.

\section{Cambio social. Permanencia del aparato de Estado}

Había que devolverle su prestigio a la vida política. Pero se practicó una dialéctica de ida y vuelta -lo que Savater llamó, (filosofía del embrague)-, para suavizar los cambios de velocidad, cada bando deseaba hacer olvidar su propio pasado: «la derecha quería manejarse con la generación del Rey, desengancharse de la guerra civil y la Victoria [...] Y la izquierda pretendía, asimismo, desengancharse de Stalin y la quema de conventos en Madrid. $)^{131}$

Estos intelectuales contribuyeron a forjar una nueva legitimidad siquiera para mantener su presencia en las nuevas instituciones, convirtiendo el medio en fin, «propiciando un discurso de la Transición en el que el consenso dejó de ser instrumento para convertirse en ideología, en discurso destinado a permitir la intervención de la izquierda en las áreas institucionales» ${ }^{132}$. De este modo, la izquierda adquirió una homologación de parte del bloque que hasta la fecha se la había negado ${ }^{133}$. Pues el papel de éste estaba justificado y el recuerdo de la democracia eliminada por la Guerra civil ya no se imponía y la conexión ideológica con el exilio tampoco. Así fue cómo se aunaron varias estrategias para oscurecer el pasado y preterir lo venidero.

\footnotetext{
127 Ibid., p. 299-300.

128 Francisco Umbral, Y Tierno Galván ascendió a los cielos, Barcelona, Seix Barral, 1990, p. 161.

129 César Alonso de los Rios, La verdad sobre Tierno Galván, Madrid, Anaya, Madrid, 1997, p.20.

130 Francisco Umbral, Y Tierno Galván ascendió a los cielos, Barcelona, Seix Barral, 1990, p.10

131 Francisco Umbral, op. cit., p. 120.

132 Ferrán Gallego, El mito de la Transición. La crisis del franquismo y los origenes de la democracia (1973-1977), Barcelona, Crítica, 2008, p. 704.

133 Jorge de Esteban, Luis López Guerra, « Radiografia de la Constitución ", Cuadernos para el Diálogo, $\mathrm{n}^{\circ} 240,3$ de diciembre de 1977 , p. 19.
} 


\section{Construir la democracia}

Estos cambios trajeron consigo la existencia de una nueva oposición capaz de plantear una dinámica política circunscrita al terreno de los hechos que exige la presencia de «políticos inteligentes y audaces», «que sepan». Tras la muerte de Franco, esos mismos hombres y mujeres, ya salidos a la vida pública nacional, se encaminaron por una senda reformista tras haber comprobado la crisis del marxismo, mientras algunos pensadores, escritores y artistas se refugiaron en un solipsismo estético. Otros condenaron los límites de un cambio político basado en una reforma pactada y un tercer grupo de intelectuales próximos al PSOE propusieron una nueva lectura del marxismo, considerando, con Manuel Sacristán, el introductor de Gramsci en España, el eurocomunismo como una degeneración del estalinismo ${ }^{134}$. La alianza de hecho del PCE con el PSOE y los democristianos de Joaquín Ruiz Giménez diluía las veleidades rupturistas del mismo al que le convenía la moderación de cara a su legalización.

Otra corriente que atrae a los jóvenes intelectuales tras el Concilio Vaticano II es el progresismo cristiano encarnado por la revista Cuadernos para el Diálogo que fomenta la discusión y el pluralismo, y en Cataluña, con un proyecto de integración europea, Serra d'Or bajo la protección de la Abadía de Montserrat ${ }^{135}$, que se dotan ambas de editoriales, Edicusa y Edicions 62 que desempeña, junto con Nova Terra un papel destacado. Por fin, en 1963, reaparece la Revista de Occidente que prosigue una tradición liberal orteguiana, poco reivindicada en aquel entonces.

Las respuestas a la encuesta "España quiere democracia», publicada por Cuadernos para el Diálogo en diciembre de $1975^{136}$ coinciden en exigir un protagonismo popular más que una «democracia impuesta desde arriba» tanto más cuanto que no hubo forma de medir el invocado "consenso» y «la estructura del poder se ha movido al margen de las reivindicaciones y aspiraciones populares» ${ }^{137}$. Por otra parte, Alfonso C. Comín recordó que « la democracia no se hereda beatíficamente [...] No existe la democracia otorgada. Es una lección conocida de la historia. Las libertades se conquistan. Esa conquista no es obra de un día, sino generalmente el resultado de una larga marcha por el calendario, las fábricas, el parlamento, de papel, las aulas y los pasillos de las Universidades, las oficinas, el cerebro atormentado a veces por la lucidez, a veces por la oscuridad, de los intelectuales. En todo caso es la conquista fe los pueblos. Pues la democracia ha exigido, alli donde se ha instaurado, el paso de una revolución política» ${ }^{138}$. Casi todos los intelectuales, profesionales, militantes políticos o sindicales y periodistas interrogados formulan tres requisitos: 1) establecimiento de todas las libertades y el reconocimiento de todos los partidos políticos; 2) amnistía, reconocimiento de los derechos políticos y de las nacionalidades del Estado español; 3) formación un gobierno provisional de amplia coalición y apertura de un período constituyente con elecciones libres.

134 Juan Ramón Capella, La práctica de Manuel Sacristán. Una biografia política, Madrid, Trotta, 2005.

135 Joan Manuel Tresserras, Enric Marin, Josep Lluis Gomez Mompart i Francesc Espinet, Intel.lectualitat i cultura resistents. « Serra d'Or » (1959-1977), Barcelona, ed. Galerada, 2001.

136 Cuadernos para el Diálogo, n¹47, diciembre de 1975. Respuestas de Nazario Aguado Aguilar, F. Garcia Agudin, Pedro Altares, Rafael Arias Salgado, Xosé M. Beirás, Juan Benet Goitia, Josefina Camacho, Pablo Castellano, Fernando Chueca Goitia, Manuel Díez-Alegria Frax, Joaquin Garrigues Walker, José Mu Gil Robles Quiñones, Raúl Morodo, Juan A. Ortega y Díaz-Ambrona, Eugenio Royo, Simón Sánchez Montero, Joaquín Satrústegui, Francisca Sauquillo Pérez del Arco, Enrique Tierno Galván, Luis Urruñuela, Vicente Ventura Beltrán, Ramón Muñagorri.

137 Pedro Altares, Ibid., p. 17.

138 Alfonso C. Comín, « En el umbral de la esperanza », Ibid., p. 19. 
Gente moderada aboga por el reconocimiento de las autonomías regionales (un ex militar, Antonio Menchaca), mientras José $\mathrm{M}^{\mathrm{a}}$ Gil Robles propone para alcanzar una democracia auténtica transformar la vida local merced a una solución federalista del Estado, «un federalismo integrador de todas nuestras particularidades regionales y étnicas, rectificador de un centralismo absurdo que esteriliza los mejores esfuerzos y superador para la realización de un gran ideal común, de sentimientos heridos y agudizados por la hostilidad y la incomprensión ${ }^{139}$. Otros requisitos a menudo enarbolados son la separación de la Iglesia y el Estado (Joaquín Satrústegui, Francisca Sauquillo, Roberto Mesa) la integración de España en el concierto de las naciones democráticas empezando por la Comunidad Europea (Mohedano, Roberto Mesa). Pero no se trataba sólo de borrón y cuenta nueva, había que asumir reivindicaciones no satisfechas: autonomía de regiones y nacionalidades, movimiento feminista etc. Cerca de este círculo cunden rumores pragmáticos: a muchos les conviene «una democracia coronada y de derechas, que nos permita ir trabajando poco a poco hacia otra cosa, recambio paulatino de hombres, elecciones generales» ${ }^{140}$. También se esbozaban instrucciones de uso más precisas todavía: «Primero se corona al Rey, así con mayúscula, luego se le da una terna para que elija presidente y luego empezamos a desarrollar las libertades a partir de lo escrito en piedra por el Régimen. Hay más materia negociable de lo que parece» ${ }^{141}$.

Ruiz Giménez recordaba, con acentos del Antiguo Testamento, una realidad política que era el carácter transitorio de los hombres (« Por grande que sea su envergadura, los hombres pasan como pasa la flor del heno, en la estremecedora expresión de los Libros sagrados») y la permanencia del Estado que no admite muchas tergiversaciones. Otra cosa es, en la práctica, la aplicación de la ley suprema:

«El Estado no pasa, no transita, en el sentido profundo del término: cambia, pero permanece; se trasmutan sus estructuras accidentales, pero queda en pie la sustancia de su misión integradora. Y en los instantes de crisis de una Sociedad, esa misión se reafirma inexorablemente. El Estado renace, una y otra vez, de sus propias cenizas y reafirma su presencia activa e inesquivable.

De aquí que quien ocupe la cumbre del Poder, aunque sea a título provisional, ha de ejercerlo sin perplejidades, en un empeño que, en sí mismo, objetivamente, es cualquier cosa menos provisional.» ${ }^{142}$

Pero el fenómeno de la Transición no fue meramente institucional ${ }^{143}$. Varios colectivos, juventudes, asociaciones femeninas etc. contribuyeron a la construcción de la democracia. Sea reivindicando un marco igualitario entre hombres y mujeres, sea con planteamientos feministas destinados a luchar conjuntamente contra la dictadura y la misoginia ${ }^{144}$. En tal caso, al enfoque de clase se juntaba la perspectiva de género a partir de una experiencia

$139 \mathrm{Ibid}$., p. 24.

140 Francisco Umbral, Y Tierno Galván..., op. cit., p. 11.

141 Ibid., p. 16.

142 Joaquín Ruız Giménez, « Los deberes del Tránsito », Cuadernos para el Diálogo, t. XII, n¹46, noviembre de 1975 , p. 6-7.

143 Victor Pérez Diaz, The return of civil society: the emergence of Democratic Spain, Cambridge, Harvard University Press, 1993.

$144 \mathrm{La}$ bibliografia sobre el particular es abundante. A título de ejemplos: Asociación de mujeres en la Transición democrática, Españolas en la Transición : de excluidas a protagonistas (1973-1982), Madrid, Biblioteca Nueva, 1999; Mary Nash, Dones en Transició. De la resistencia politica a la legitimidad feminista : las dones en la Barcelona de la Transició, Barcelona, Ajuntament de Barcelona y Regidoria de la Dona, 2007.; Carmen Martinez, Purificación Gutiérrez y Pilar González, El movimiento feminista en España en los años setenta, Madrid, Cátedra, 2009. 
antifranquista, a menudo la ayuda a los presos políticos, en la que su situación fue subsidiaria ${ }^{145}$ pero cada vez más colectiva y organizada por el PCE en una nueva asociación de mujeres que alcanzaba algunas disidentes del catolicismo progresivo ${ }^{146}$, hasta la creación en 1964, en la clandestinidad, del Movimiento Democrático de Mujeres, dispuesto a luchar también contra la discriminación, que intentó dotarse de una red nacional pero acabó renunciando a crear un movimiento de masas. Por fin, en 1976, el MDM se unió al Movimiento de Liberación de la Mujer. Las Jornadas Catalanas de la Dona en mayo de 1976, y las II Jornadas Estatales de la Mujer de Granada en 1979, fueron un foro donde se debatió sobre feminismo y se trató de definir estrategias para lograr la liberación de la mujer. Luego el movimiento convergió en una movilización pro-amnistía que acabó en una doble movilización política y feminista, mientras la línea del feminismo radical creaba en 1979 el Partido Feminista ${ }^{147}$ y las demás se acogían a las estrategias de los partidos de izquierdas.

\section{Una dialéctica inconclusa}

Si la Transición es una apelación inventada a posteriori por gente que creyó haber llegado a la meta, el uso del concepto de preTransición es doblemente falaz pues pretende homologar la Transición desde la doble perspectiva anterior y posterior es decir, franquista y democrática, que forjando luego el discurso de las tres legitimaciones de la monarquía (franquista, monárquica, democrática) para hacer olvidar que el franquismo instauró la monarquía que propició dicha Transición.

A lo largo de ésta se homologaron tácitamente los partidos políticos que podían gobernar porque eran democráticos. Éstos fueron acusados de haber alentado la amnesia colectiva mientras los españoles no habían olvidado su pasado pero optaban por la democracia como se lo recordaron entonces a su manera Julián Marías ${ }^{148}$ o Raúl Morodo quien estaba convencido de que una negociación con el Poder era inevitable porque la favorecía la actitud reformadora del gabinete Suárez: «No tenemos, es cierto, instituciones democráticas, pero somos ya un pueblo democrático». Articular la mentalidad existente y generalizada de todas las clases sociales españolas a unas instituciones que definan y expongan esta mentalidad es el objetivo político primordial en este año de 1977$\rangle^{149}$. Esta actitud le inspiró a Francisco Umbral este comentario anclado en una comparación con el régimen de la Restauración: «Parece que el canovismo vuelve a ser el "proyecto sugestivo de vida en común" que algunos están muñendo para España. [...] Morodo, con sus pluralidades políticas, es un ejemplo/ameba, al más alto grado, de cómo un joven político español puede ir transicionando y sirviendo para muchas cosas. Cientos de Morodos se quedarían fosilizados en un sagastacanovismo que pretenda estabilizar el país $»^{150}$. Situación que resumiría, unos años después, Juan José Millás proponiendo un método singular con este

145 Ana Belén Gómez FernÁndez, «Del antifranquismo al feminismo : la búsqueda de una nueva ciudadanía Pasado y Memoria, $\mathrm{n}^{\circ} 13$, Universidad de Alicante, 2014, p. 251-270.

146 Francisco Arriero, «El Movimiento Democrático de Mujeres: del antifranquismo a la movilización vecinal y feminista », Historia, Trabajo y Sociedad, n 2, 2011, p. 33-62.

$147 \mathrm{M}^{\mathrm{a}}$ Carmen Garcia NiEto, Ordenamiento juridico y realidad social de las mujeres. Siglos XVI- XX, Madrid, U.A.M., 1986, p. 453-462; Elena Grau, « De la emancipación a la liberación y la valoración de la diferencia. El movimiento de mujeres en el Estado español, 1965-1990 w, Georges DuBy y Michelle Perrot, (dir.), Historia de las mujeres. El siglo XX. Vol. 5, Madrid, Taurus, 1993, pp. 673-683.

148 Julián Marias, El País, 24 de agosto de 1976.

149 Raúl Morodo, «La reforma de la ruptura y la politica del consenso», El País, 7 de enero de 1977.

150 Francisco Umbral, «El sagastacanovismo. Spleen de Madrid», El País, 24 de abril de 1983. 
aforismo desilusionado: «La mejor política es la de los hombres de derecha con ideas de izquierda y de los hombres de izquierda con ideas de derecha» ${ }^{151}$. O calificando a los ciudadanos con una adjetivación digna de los más irónicos diagnósticos de Unamuno sobre el régimen de la Restauración, sentenciaba: «El cuerpo electoral está constituido por indecisos, vergonzosos y derrotistas $\rangle^{152}$. Dicho de otra manera, tras el efecto lenitivo del consenso, tampoco engendraba gran entusiasmo la alternancia democrática. Hasta tal punto que se habló de «una democracia incompleta» ${ }^{153}$, y de la necesidad de una «segunda Transición». Este nueva Transición anhelada hubiera propiciado una solución a corto plazo hipotecando el futuro. Numerosos autores, desde Juan Luis Cebrián hasta Gregorio Morán, criticaron este proceso, mientras José María Aznar apelaba a una segunda Transición para subsanar los daños que hubiera hecho " el felipismo» ${ }^{154}$.

La crítica del papel de los intelectuales en estas circunstancias deja la impresión no de un fracaso sino de un proceso inacabado. La cultura de la oposición a la dictadura no era la misma que la de la Transición a la democracia. Tras haber llevado a cabo una autocrítica religiosa (primera mitad de los cincuenta cuando es ministro de Educación Ruiz Giménez), social (segunda mitad de los cincuenta) y finalmente política (a lo largo de los años sesenta con la revista Cuadernos para el Diálogo), vacilando todavía entre la necesidad de erigirse en conciencia de la multitud y ser un miembro egregio de una minoría selecta, el intelectual del tardofranquismo había sido definido por Ruiz Giménez o Aranguren como moralista:

«Quienes ejercen hoy públicamente el viejo oficio de moralistas son precisamente los intelectuales cuya función es la de constituir la conciencia moral de la sociedad como demanda y exigencia, como voz de la porción minoritaria más avanzada y disponible de la sociedad.» ${ }^{155}$

Pero esta concepción parece prolongar el enfoque relativista de Laín Entralgo quien comprueba, en 1957 que el intelectual occidental descubre la contingencia pues «la ciencia de hoy ha perdido su pretensión de saber decisivo y absoluto» ${ }^{156}$. El intelectual católico «arrojado» conoce la "opresión del mundo» en el seno de la actual sociedad española ${ }^{157}$, y el otro más retraído, a quien llama « confinado », también echa en falta, a su parecer, el contacto con el mundo exterior. En un contexto en que se quiso soslayar las contradicciones reveladas por la nueva realidad (es decir una subcultura de masas forjada por la experiencia federativa de revistas como Triunfo o Cuadernos para el Diálogo y una cultura política elaborada por un grupo de intelectuales que fueron falangistas en su juventud y creyeron posible una integración de los vencidos en el campo de los vencedores) la Transición apareció pues más como una panacea, a la que parecieron resignarse todos, que como un problema que exigía, más allá del cambio institucional, una definición más precisa de la forma del Estado.

151 Juan José Millas, «Qué lío!», El País, Madrid, 4 de octubre de 1991.

152 Juan José MiLlas, «Indecisos», El Pais, Madrid, 15 de enero de 1993.

153 Vicenç Navarro, «Consecuencias de la Transición inmodélica» El País, 8 de enero de 2003.

154 Juan Luis CeBrian, La España que bosteza. Apuntes para una historia critica de la Transición, 1981 ; Gregorio Moran, El precio de la Transición, 1991; José Maria Aznar, España : la segunda Transición, 1994.

155 José Luis López Aranguren, Memorias y esperanzas españolas, Madrid, 1969.

156 Pedro Laín Entral.go, « El intelectual católico en la sociedad actual », art. citado, p. 47.

157 Ibid., p. 53. 
¿Fue la Transición, un medio, un fin, un método o un mito? Sin duda todo esto a la vez. El período estudiado plantea varios problemas cronológicos y conceptuales. ¿Designa sólo el período constituyente o abarca la aplicación posterior de la nueva ley suprema? La vida política presentaba otra fisonomía, pero mantenía la misma anatomía: los poderes fácticos y las élites económicas no habían cambiado, ni podían hacerlo en tal contexto en el que nadie quería desmantelar ni disolver nada, sino al contrario reagrupar, agregar para entrar como sujeto jurídico en el nuevo juego de las fuerzas colectivas. En cuanto al papel desempeñado por el intelectual en tal proceso es a la vez relevante e irrisorio. La idea misma del intelectual comprometido pareció una antigualla. Como en la Francia de 1983, se produjo el llamado «silencio de los intelectuales» ${ }^{158}$, es decir su «privatización», el hecho de que hubieran abandonado el discurso crítico para transformarse en expertos económicos o sociales consultados por estados mayores de partidos políticos o el mismo poder. Los últimos estertores del compromiso del intelectual se produjeron en torno al referéndum sobre la oportunidad de adherirse a la OTAN. Luego volvieron a salir brevemente a la vida pública para pedir la moralización de la vida pública al final del gobierno de Felipe González y su protesta volvió a ser intermitente.

Sin embargo, regularmente renace en España, a finales de los años ochenta y principios de los noventa, el debate en torno a la identidad, la utilidad ${ }^{159}$, el papel ${ }^{160}$, la desaparición, el silencio $^{161}$ o la exuberancia del intelectual ${ }^{162}$. Éste es descrito como solitario ${ }^{163}$, tiránico ${ }^{164}$,

158 Max Gallo, «Les intellectuels, la politique et la modernité », Le Monde, 26 de julio de 1983.

159 Josep-Vicent Marques, «Ser o no ser intelectual », El Pais, Babelia, 16 de noviembre de 1991, p. 2; José Ángel VAlente, "Los intelectuales están domesticados", El Pais, 24 de julio de 1994.

160 Manuel TuÑón DE LARA, «La vigilancia del intelectual», El País, 6 de junio de 1984; «El intelectual y el horizonte 2000», EI País, 13 de mayo de 1982.

161 Paul Aubert, " La fin des intellectuels ou le désir de totalité », Obliques, éd. Borderie, Paris, $\mathrm{n}^{\circ}$ Sartre inédit, 1979, p. 301-305; « La disparition de l'intellectuel », (Actes du Colloque de Cerisy sur Sartre, juin 1979), Etudes sartriennes, II-III, Cahiers de sémiotique textuelle, n5-6, 1986, Université de Paris X, p. 133-137; "Moral und Politik bei Jean-Paul Sartre», Jürgen Sieß (ed.), Frankfurt-New York, Campus Verlag, 1984, p. 173-199. «Entre las notables desapariciones de este tiempo está la de los intelectuales: su historia comienza con el proceso Dreyfuss (sic), al empezar el siglo, y está terminando ahora: los intelectuales europeos han brillado cien años, pero probablemente ni uno más (hay diplodocos supervivientes: les espera el frío, el hambre, la caza). » (Eduardo Haro Tecglen, " "Por el racismo hacia Dios". Folletin de un año largo. Cap. 5), El Pais, 5 de agosto de 1993). Juan Marichal, «Los intelectuales están en la reserva», El Pais, 5 de abril de 1989.

162 José Luis Lopez Aranguren, « El Poder aún padece vicios franquistas», $A B C, 23$ de marzo de 1994.

163 Antonio Hernández GIL, «La figura imprecisa del intelectual », $A B C, 13$ de enero de 1988. Jordi Solé Tura, «El poder no acaba de fiarse del intelectual », El País, 13 de octubre de 1991.

164 Antonio Muñoz Molina, "Los intelectuales comprometidos son un peligro », Tiempo, 24 de febrero de 1992. 
responsable $\mathrm{e}^{165}$ e irresponsable $\mathrm{e}^{166}$, inoportuno $\mathrm{u}$ oportunista ${ }^{167}$, orgánico ${ }^{168}$, traidor $^{169}$, silencioso ${ }^{170}$, domesticado ${ }^{171}$, práctico ${ }^{172}$ o colectivo ${ }^{173}$. Se reflexiona sobre el futuro del intelectual después de haber recordado las condiciones sociológicas y morales de su nacimiento: «los intelectuales asumieron en Francia ... el oficio totalmente secularizado ya, del clérigo: predicación de lo que se ha de hacer, no en el ámbito de la conducta privada, sino moralmente en el del comportamiento público», apunta Aranguren ${ }^{174}$, mientras Ayala no acaba de entender la prudencia del intelectual español, que tampoco ahora ha elegido entre ser conciencia de la multitud y minoría selecta, cuyo compromiso consiste, a su parecer, sólo en escribir en la prensa: «La satisfacción moral de sentirse limpios en su noble lucha frente al poder, pues el problema planteado por Sartre en Les mains sales no se les muestra evidente cuando lo que con ellas están haciendo no consiste por cierto en poner bombas o disparar la metralleta, sino en escribir un habilidoso artículo para ver si cuela» ${ }^{175}$. Pero el renacimiento del intelectual tradicional parecía improbable. A Muñoz Molina, por ejemplo, no le convence la perspectiva de la vuelta del intelectual sartriano: «Los intelectuales comprometidos son un peligro "), advierte, denunciando una posible tiranía de éstos ${ }^{176}$; cuando al contrario Vázquez Montalbán les asigna la misión de procurar arreglar el desorden social: «Hoy hay otro desorden y la obligación de los intelectuales

165 Jesús IвÁÑez, «La responsabilidad de los intelectuales », en Por una sociología de la vida cotidiana, Madrid, Siglo XXI, 1994, p. 242.

166 José Luis Corcuera declaró cuando criticaron la ley de seguridad pública (Ley orgánica 1/92 de 21 de febrero de 1992) que lleva su nombre: « Hay [en España] más pseudointelectuales por metro cuadrado que en ningún país europeo (citado por José A. Gabriel y GaLÁN, « Los intelectuales », El Sol, 15 de octubre de 1991. Sobre el particular, apunta Haro TeCGLeN : "Los rebeldes callados sirven poco: solamente si esperan el momento de hablar, el de ser mayores. No la van a encontrar. Hay poco intelectual, en el buen sentido de la palabra: aunque yo conozco unos cuantos de primer orden. Si hubiese más y hablaran libremente y tuvieran medios donde expresarse, no habría ministros como Corcuera. El pensamiento, el conocimiento, la razón, el entendimiento, influirian sobre la política, o sobre los electores. No habría debates como éste.» (Eduardo Haro TeCGLEN, « La crema de la intelectualidad», El Pais, 11 de octubre de 1991).

167 Fernando SAVATER, « Los intelectuales y la afición », El Pais, 25 de julio de 1994.

168 «Hay pocos intelectuales y tienden a convertirse en intelectuales orgánicos ideólogos de partido 》 (José Luis Lopez Aranguren, « Entrevista por José Echenagusía ", Alfoz, n $65,1^{\circ}$ de septiembre de 1989 , p. 13-17); Félix ORTEGA, « Los nuevos intelectuales orgánicos», Claves de razón práctica, $\mathrm{n}^{\circ} 24$, julio de 1992; Francisco AyalA, «El intelectual orgánico», El País, 5 de mayo de 1991. «En estos dias se ha hablado mucho -mucho y mal- del intelectual orgánico. Si no me equivoco, por intelectual orgánico debe entenderse aquel que se encuentra integrado y actúa dentro del aparato del poder de la sociedad. 》

169 Fernando Rodrigo, «La traición de los intelectuales», El Pais, 16 de abril de 1994 ; Amando DE Miguel, «Los intelectuales no son, por necesidad, los que se enfrentan a los problemas colectivos, son también los que los enmascaran» (citado por Jorge CeLA TRULOCK, "¿Y los intelectuales? », ABC, 20 de julio de 1994).

170 Jorge Cela Trulock, "¿Y los intelectuales ? », $A B C, 20$ de julio de 1994.

171 « Los intelectuales de hoy o guardan silencio o están domesticados por el Poder », (José Luis LóPEZ Aranguren, «Aranguren habla de su autobiografia intelectual», El País, 2 de marzo de 1992).

172 Joaquín Estefania, «Reivindicación del intelectual práctico», El Pais, 12 de julio de 1992.

173 Aranguren cree que pasó el tiempo de los grandes intelectuales solitarios. Por intelectual orgánico debe entenderse aquel que se encuentra integrado y actúa dentro del aparato del poder de la sociedad. Y como Jean-Paul Sartre a final de su vida, Aranguren se refiere al intelectual colectivo. José Luis LóPEZ ArANGUREN, "Fin de semana con...Los intelectuales hemos perdido la vigencia social», El Pais, 26 de julio de 1992.

174 José Luis López ArAnguren, «El futuro del intelectual », Leonardo, abril 1992, p. 36.

175 Francisco AyALA, «El intelectual orgánico», El Pais, 5 de mayo de 1991.

176 Antonio Muñoz Molina, «Los intelectuales comprometidos son un peligro », Tiempo, 24 de febrero de 1992. 
es testimoniar sobre ese desorden, explicar sus claves y tratar de aportar soluciones a ese desorden $\rangle^{177}$.

Se cree incluso que una acción internacional de los intelectuales puede ser benéfica. De nuevo, tras el «Tribunal Russell» de los años sesenta, que quiso enjuiciar la Guerra de Vietnam, se habla en los años noventa, después del sitio de Sarajevo, de la oportunidad de constituir un parlamento de intelectuales que hiciera de conciencia moral de nuestro tiempo. Los intelectuales españoles no son insensibles a esta iniciativa que recuerda el modelo del Congreso de Escritores celebrado en Valencia en 1937. Al ministro de Cultura francés, que se opuso a ella con el argumento de que no quería que los escritores del mundo abrieran un corredor de salida a los intelectuales de Sarajevo, subrayando que el beneficio de una acción tal sería exclusivamente para los intelectuales, Juan Goytisolo le preguntó en una de las sesiones celebrada en Estrasburgo: «¿Cuál es la cultura que representan estos ministros de la Cultura si no escuchan la voz de quienes la producen?». Pero esta negativa institucional explicada por la posición proserbia de algunos gobiernos europeos, no amedrentó a los intelectuales, que contemplaron un momento la posibilidad de presentar una lista de intelectuales en las elecciones europeas de $1994^{178}$, aunque finalmente la propuesta de Juan Goytisolo y Susan Sontang de celebrar una reunión en Sarajevo no prosperó. Jacques Derrida quiso explicar este compromiso por la necesidad de «intervenir para abrir los ojos de aquellos que no alcanzan a ver los peligros que acechan a la sociedad $)^{179}$.

En pocos meses, nunca se había hablado tanto de los intelectuales. Se barajaron todas las definiciones y opciones hasta el ensanchamiento mediático de su base protestataria. Los títulos de los últimos manifiestos unían, en la denuncia de la corrupción del final del último Gobierno de Felipe González, « intelectuales y artistas» ${ }^{180}$. «Ahora se hace más necesaria la figura del intelectual, que es el defensor de la ética frente a la política. [...] Nuestro papel es sólo crítico», repetía a la sazón Aranguren, volviendo a definir al intelectual como avizor y conciencia moral.

\section{Conclusión}

Estas nuevas definiciones internacionales o colectivas de los intelectuales revelan también que éstos se percataron de la fragilidad de su obra. Aunque se alude a ella sobre el modo conmemorativo, como discurso de los orígenes, hay quien opina que la Transición no supo crear su objeto ni está terminada. Pues no era sólo la democracia, era una promesa indefinida que vascos y catalanes u organizaciones feministas quisieron aprovechar para

177 Manuel Vázquez Montalban, Congreso de intelectuales y artistas, 4 vols. Valencia, Generalitat Valenciana, 1987. Carlos BERBELL, «Los intelectuales denuncian la hipocresía nacional». «Un pais bajo sospecha), Panorama, n² 245, 3 de febrero de 1992, p. 19. Testimonios de José Luis López Aranguren, Enrique Fuentes Quintana, Javier Sábada, Ramón Tamames, Fernando Savater, José Manuel Caballero Bonald, Amando de Miguel.

178 Formaban parte de este grupo internacional impulsado un momento por Bernard-Henri Lévy: Jacques Derrida, Pierre Bourdieu, Jean-Luc Nancy, Juan Goytisolo, Susan Sontang, Günter Grass, Paul Auster, Carlos Fuentes etc., bajo la presidencia de Octavio Paz.

179 «Los compromisos dan miedo», El Tiempo, Bogotá, 15 de noviembre de 1993.

180 Consuelo Font, Lucia HuÉlamo, Nuria VARELA, «Intelectuales y artistas al asalto de la política. La abstención y el desencanto obligan a los partidos a aprovechar el carisma de los famosos», Panorama, $\mathrm{n}^{\circ} 255,13$ de abril de 1992, p. 9-14; « Cientos de intelectuales y artistas apoyan la huelga del 27-E», El Mundo, 6 de enero de 1994; "Intelectuales y artistas españoles piden respeto a los derechos humanos», El Pais, 12 de enero de 1994; «Intelectuales indignados. Escritores artistas y cineastas reaccionan ante los escándalos de corrupción política», El Pais, 19 de abril de 1994. 
reivindicar una forma de democracia superior que les diera mayor peso, pero que también alimentaron ciertos intelectuales sumando el irenismo y el historicismo para acabar con un franquismo que no era ideológicamente unitario. Finalmente, para los intelectuales, la Transición fue una actitud, una conducta, más que un proyecto. Había que perfeccionar una historia colectiva fuera de las estructuras anteriores de identificación. Pero recobrar los valores de una pertenencia colectiva en la ultima ratio que supedita el porvenir a un eterno presente, conllevaba algunos riesgos.

Los intelectuales se habían asignado tres fines estrechamente unidos: recuperar el pasado sustraído o perdido, luchar por la libertad, dibujar un futuro. El resurgir de la cultura liberal ni la homologación de la herencia del exilio bastaban. El diálogo con los niños del interior (cuando hijos de vencedores y vencidos empezaron a compartir reivindicaciones y a firmar conjuntamente manifiestos) y el parcial reencuentro con el exilio hicieron fracasar muy pronto las veleidades franquistas de refundar la historia. Ahora les tocaba a los intelectuales asignar un sentido a esta dialéctica inconclusa y hacer funcionar un Estado todavía indefinido, sin olvidar que la Constitución es un medio y no un fin, ni que: «la democracia es el enigma resuelto de todas las constituciones» ${ }^{181}$. No pueden confundirse la ley suprema y el juego político que propicia.

Más que el comentario sobre la misión del intelectual, se impuso la evocación de su desaparición o más bien una especie de distanciamiento que haría de él tan sólo un observador crítico - «vigilante de los vigilantes», dirá Aranguren ${ }^{182}-$, aunque lo que se ha tomado por su muerte era sólo su silencio. Pues ya no persigue ninguna verdad absoluta en nombre de un sujeto universal, como el intelectual católico, cuando quiso contrarrestar las pretensiones del intelectual liberal o socialista, ni ningún deseo de ver triunfar una revolución ${ }^{183}$. Tampoco aspira a ejercer el poder ni a suplantar a los políticos. Esta coyuntura corresponde pues al fin de los viejos maestros, a la liquidación de los grandes relatos ${ }^{184}$, y a la necesidad de unos observadores críticos que asumen los principios constitutivos de la sociedad democrática: este cambio en los comportamientos sociales también fue una transición, por no decir una novedad. No obstante, para el intelectual, esta nueva actitud conllevaba el riesgo de privilegiar la comunicación aferrándose a una ficción metodológica destinada a mostrar las formas inevitables de autonomización de lo social.

181 Karl MarX, Critique du droit politique hégelien, Paris, Éditions Sociales, 1976, p. 68.

182 José Luis López Aranguren, «El intelectual. La vigilancia de la vigilancia », El País, 16 de julio de 1976.

183 Congreso internacional de intelectuales y artistas, Valencia, Generalitat valenciana, 1987, t.I, p. 44.

184 Véase, Santos Julı̇, Historias de las dos Españas, Madrid, Taurus, 2004. 